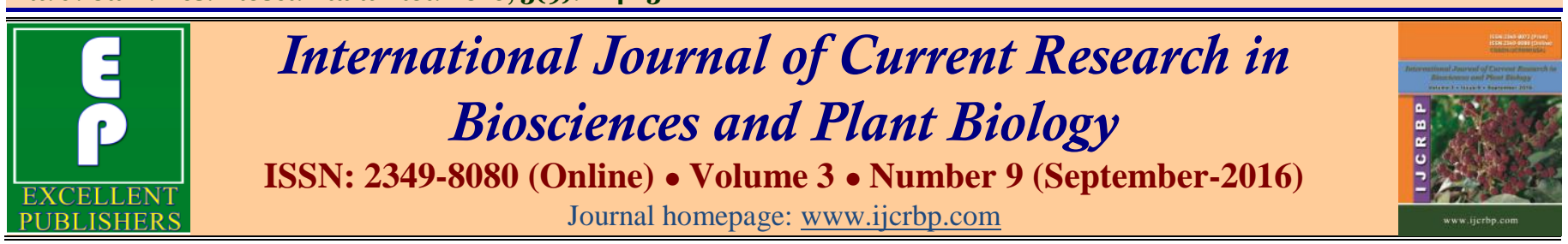

\title{
Impact of Wood Cutting and Bush Fire on the Dynamic of Regeneration in the Guinea Savanna of Adamawa Region
}

\author{
Tchobsala $^{1 *}$, Ranava Dieudonne ${ }^{1}$, Ibrahima Adamou' ${ }^{1}$ and Mbolo Marie² \\ ${ }^{1}$ University of Ngaoundéré, Faculty of Science, Department of Biology Science, Biodiversity Laboratory and Sustainable \\ Development, P.O. Box 454 Ngaoundéré, Cameroon \\ 'University of Yaoundé I, Faculty of Science, Department of Biology and Plant Physiology, P. O. Box 812, Yaoundé, Cameroon \\ *Corresponding author.
}

\begin{abstract}
A bstract
The aim of this work was to study the impact of wood cutting and bush fire on the dynamics of regeneration of vegetation in the Guinea savanna of Adamawa. Floristic inventories were made by using quadrat method of two factors (shrubby and savanna), three treatments (logging without fire, with fire and control) and three repetitions (parcels). Within each savanna, 09 sites of $10 \mathrm{~m} \times 10 \mathrm{~m}$ were delimited using the pocket for both savannas. Data analyses with Xlstat software showed that the regeneration rate is very high in the savanna logging without bush fire. The vegetation structure of both savannas following the dispersal of species in «L» representing the evolution and the higher rate of the regeneration of species after wood logging. The Shannon index respectively in the tree savannas and shrubby savanna is $3.74 \%$ and $2.70 \%$ for the site cut without fire, $3.61 \%$ and $2.53 \%$, for the site cut with fire and $3.75 \%$ and $2.80 \%$ for the control site. These Shannon indexes show that bush fire and wood cut influence the regeneration of the ligneous. Forbidden wood cut, uncontrolled fire, strict sanction and awareness of the population are the solution for a sustainable management of Guinean savannas.
\end{abstract}

\section{Introduction}

The increase of population and the exploitation of natural resources for speculative purpose lead to environmental degradation. This degradation is manifested by loss of biodiversity, fragmentation of forest, decrease of soil fertility, loss of ecosystem productivity, especially those of tropical forest (Ibrahima et al., 2002). The subSaharan Africa vegetation in general and particularly the one among those is Cameroon is harmed by deforestation which is manifested by the unexpected increase of population in search of natural resources (Anonymous, 2015). Environment in all its diversity is both a necessary living space and delicate for the perpetuation of living organisms. The human pressure and land cover

\section{Article Info}

Accepted: 31 August 2016

Available Online: 06 September 2016

\section{Keywords}

Bush fire

Regeneration dynamics

Savanna

Wood cutting is responsible for soil degradation and climate change (Peltier et al., 2007). This space would be endangered when its exploitation has been uneven and anarchic. The degradation of theses forest and the ecological extinction threats resources are the preoccupation of the international agenda for a sustainable management (Dogmo, 2002). A savanna is fragile ecosystem because of the coexistence of herbaceous and woody stratum. They are dynamic systems whose evolution depends on intensity of environmental factor (wood cut, drought, fire, breeding and agriculture). The conditions of their persistence are very complex and poorly understood. They have been the subject of numerous studies (Walker and Noy, 1982; Gignoux et al., 1997; Jeltsch et al., 2000) that came out with the conclusion that most are kept in 
their state by fire. FAO (2002) have shown that this situation together with climate change in the recent decades has increased and caused extreme poverty to rural population. Wood cut and bush fire have cause deforestation. These two concepts have relationship and caused climate change. Their pressure on ecosystems in the sudano-guinean zone increases gradually with the growth of population. The latter growth has a pressure on natural ecosystems (Bellefontaine et al., 2001; Degrande et al., 2007; Mapongmetsem et al., 2011).

Savannas are particularly exposed to important risks of degradation, the important part located in semi-arid or arid zones and shelter important world population (Reynold et al., 2007). The question of their sustainability is a major issue because of their importance in agricultural, ecological and environmental (Sere, 1994; Ancey, 1996; Boutonnet et al., 2001). The role of bush fire in the dynamic of regeneration of savanna has not been well established, specially the method of the use of these fire. Bush fires can cause the disruption of the biogeochemical cycle of vegetation which can lead to negative or positive impact on productivity of natural ecosystem. These impacts have been approved by the scientific community (Louppe et al., 1995). Our study area, wood cut and bush fire are real threats to the protection of natural resources. These savannas undergo strong anthropogenic pressures such as deforestation, overgrazing, especially bush fire as it is the case in guinea savanna of Cameroon (Tchobsala et al., 2011).

A study on the correlation between «cut, fire, and regeneration dynamic of vegetation » would help us to show that if fire is recognized as an explanatory factor of the dynamic of savannah vegetation its importance and role are still not clearly defined (Jeltsch et al., 2000). Several studies were carried out by Ntoupka (1994) on the dynamic of a savanna in the Sudano-Sahelian region of northern Cameroon with the aim to combined effect of grazing, fire and wood cutting; on mount Cameroon by Ndam (1998) on the regeneration of trees and dynamic of vegetation; in Senegal by Faye (2002) on the dynamics of natural regeneration of vegetation and those of Tchobsala (2011) on impact of wood logging on natural vegetation in the suburban area of Ngaoundere. There has been no study on the impact of complex wood cut and bush fire on the dynamic of vegetation regeneration in the locality of Dori and Bini that are damaged by wood cut and bush fire. This work aims to assess i) the rate of regeneration and mortality by the combined effects of complex wood cut and bush fire; ii) the influences of wood cut and bush fire on the floristic composition and dynamic of vegetation and iii) the specific contribution of herbaceous layer under the influence of wood cut and bush fire.

\section{Materials and methods}

\section{Study area}

Adamawa region is located between the 6 and 8 degrees north latitude and between the 11 and 15 degrees east longitude. It covers an area of $63,701 \mathrm{~km}^{2}$ with an altitude between 900 and $1500 \mathrm{~m}$. Its climate is SudanoGuinean altitude with an annual rainfall of $1575 \mathrm{~mm}$ spread over 7-8 months. The annual average temperature is $22^{\circ} \mathrm{C}$ (Amougou et al., 2015). The highlands of Adamawa constitute the transitional zone, between the north of Sudano-Sahelian zone and the forest of south. Adamawa region borders the Central African Republic in the East and Nigeria in the West. This mountainous area marks the border between, southern Cameroon forest and the northern savannah. With a surface of $64,000 \mathrm{~km}^{2}$ it is the 3rd region of Cameroon by size. It stretches about $400 \mathrm{~km}$ between Nigeria and the Central African Republic and culminates at $2460 \mathrm{~m}$ above sea level atop Tchabal Mbabo (Tchotsoua and Gonne, 2010). Geographically Adamawa belongs to the Sudanian zone but the altitude introduced a variant Mountain (Fig. 1).

\section{Floristic survey method}

The floristic survey was conducted using the quadrat method, successfully applied by Yonkeu (1993) and Tchobsala (2011) in Guinean savannas of Adamaoua. This method consists of delineating an area of $10 \mathrm{~m} \times 10 \mathrm{~m}$ with a decameter within which measurements of dendrometric parameters (height of trees and shrubs, the diameters of the bunch and circumference at $0.30 \mathrm{~m}$ and $1.30 \mathrm{~m}$ ) are carried out together with the counting of living and dead individuals. For both savannas, three (3) treatments (cut without fire (CSF), cut with fire (CAF) and the control site (ST) were selected. In each treatment, three surveys were conducted on plots of $10 \mathrm{~m}$ $\times 10 \mathrm{~m}$, with a total of eighteen records for whole. These surveys were conducted for 12 months.

\section{Data analyses}

Data analyses were made using Statgraphic software. Analyses of variance (ANOVA) were on parameters such as the height, size, presence and number. Excel was used to generate the graphs and histograms. Xlstat was used to realize the principal component analysis (PCA). 


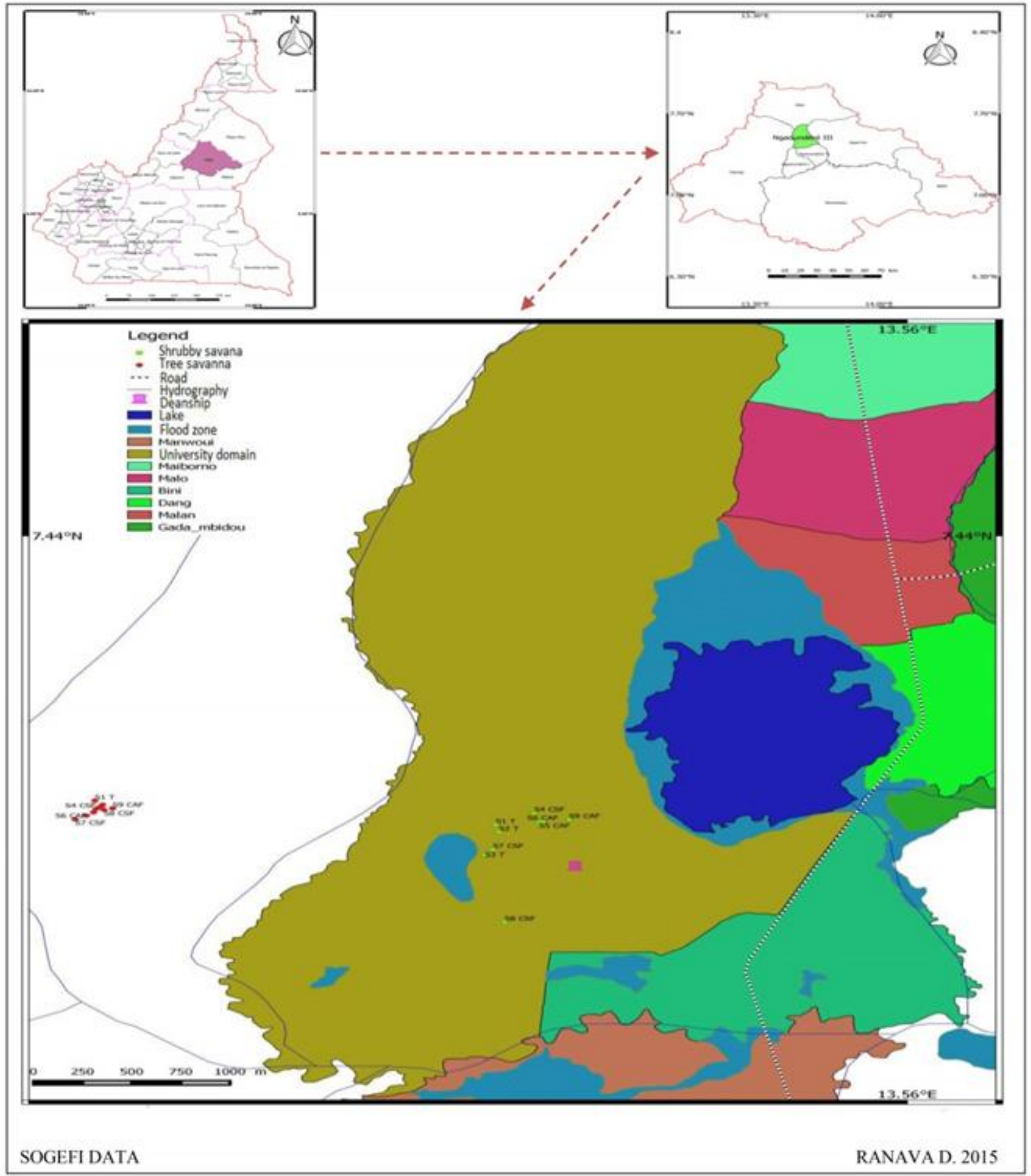

Fig. 1: Map of the study area.

\section{Technical analysis of dispersal agents of diaspores promoting regeneration}

Types of dispersal were determined by the classification of Dansereau and Lems (1957), Bonn (2004) cited by Vittoz and Engler in 2007. Table 1 shows the different types and mode of dispersal.

\section{Calculations of parameter}

Several methods are involved and include concepts of presence, centesimal frequency of a species, specific contribution and overall recovery, and these parameter calculations were done as per the procedures of Daget and Poissonnet (1972). 
Table 1. Types and modes of dissemination.

\begin{tabular}{|c|c|c|}
\hline Modes of dissemination & & Types of dissemination \\
\hline \multirow[t]{4}{*}{ Hydrochory } & Peochores & Diaspore that have a flotation appendix \\
\hline & Sarcochores & Diaspore totally or portly fleshy \\
\hline & Ombrahydrochory & Rain open the fruit when falling \\
\hline & Nautochory & Water is the transport agent of seeds \\
\hline \multirow{3}{*}{ Zoochory } & Endozoochory & Seed ingested and rejection by animals \\
\hline & Myrmecochory & Presence of substance attracting animal for transport \\
\hline & Barrochores & Diaspore not fleshy, heavy \\
\hline Anémochory & Pterochores & Diaspore that have wing-shaped appendix \\
\hline
\end{tabular}

\section{Relative density}

The relative density (DRe) or relative abundance is the relation between the number of subjects, species and the total number of all the subjects of all the species found in the area considered multiplied by 100 .

\section{Frequencies of the ligneous species}

The absolute frequency of a species $i$ is the number of records containing that species. According to BraunBlanquet (1932), the relative frequency is the percentage proportion between the number of records containing this species and the total number of records by 100 . This method determines the accidental species, accessories, fairly frequent, frequent and very or much frequent species (Table 2).

Table 2. Frequency Index (Braun-Blanquet, 1932).

\begin{tabular}{lll}
\hline Index & Frequency & Type of species \\
\hline I & F $<20$ & Accidental species \\
II & $20<\mathrm{F}<40$ & Accessory species \\
III & $40<\mathrm{F}<60$ & Fairly frequent species \\
IV & $60<\mathrm{F}<80$ & Frequent species \\
V & $80<\mathrm{F} \leq 100$ & Very or much frequent species \\
\hline
\end{tabular}

\section{Relative dominance}

The Relative dominance (Red) is the relation between the earth surface or basa surface (bs) of a species over the total earth surface of all the subject found in the area. $\mathrm{Bs}=\pi \mathrm{D} 2 / 4$. $\mathrm{D}$ is the stem diameter.

\section{The relative importance value of Curtis}

It is the total amount of the frequency, the relative abundance and density.

\section{The floristic diversity indexes}

The presence of a specie or species in an environment depends on three elements: its affinity with environmental conditions, its ability to withstand competition with other species and the ability of its diaspores to reach the middle.

Species diversity according to Barbault (1992) takes into account the relative abundance of species in addition to their number, thus substituting species richness, which reflects the total number of species present in a community. Guedje (2002) defines the species richness as the total number of species of the observed distribution. According to Frontier and Pichod-Viale (1993), taxonomic diversity depends on two concepts: the number of different taxa and how individuals are distributed among different taxa.

\section{The diversity index of Shannon}

$\mathrm{ISH}=-\Sigma \mathrm{Ni} / \mathrm{N} \log 2(\mathrm{Ni} / \mathrm{N})$, where $\mathrm{Ni}$ is the number of species.

\section{The fairness (EQ) of Pielou (1966)}

$\mathrm{EQ}=\mathrm{ISH} / \log 2 \mathrm{~N}$; corresponding to the ratio between the observed diversity and the maximum diversity number of species $\mathrm{N}$ possible. 


\section{Results}

Influence of wood cut and bush fire on the regeneration and mortality of plant according to the vegetation

The regeneration is higher in tree savanna than shrubby savanna. Therefore the number of rejection changes according to a site and vegetation formation (Fig. 2). The number of rejection is higher in CSF followed by CAF site and control site. In the tree savanna, the CSFAB has $85.97 \%$ of rejection and $14.03 \%$ of death plant; CAFAB $81.40 \%$ of rejection $18.60 \%$ of death plant, TSAB $90.22 \%$ of rejection and $9.88 \%$ of death plant. In contrary, in shrubby savanna there is $74.46 \%$ of rejection and $25.24 \%$ of death plant for CSF; $84.17 \%$ of rejection and $15.23 \%$ of death plant for CAF and the control site has $81.38 \%$ of rejection and $18.62 \%$ of death plant.

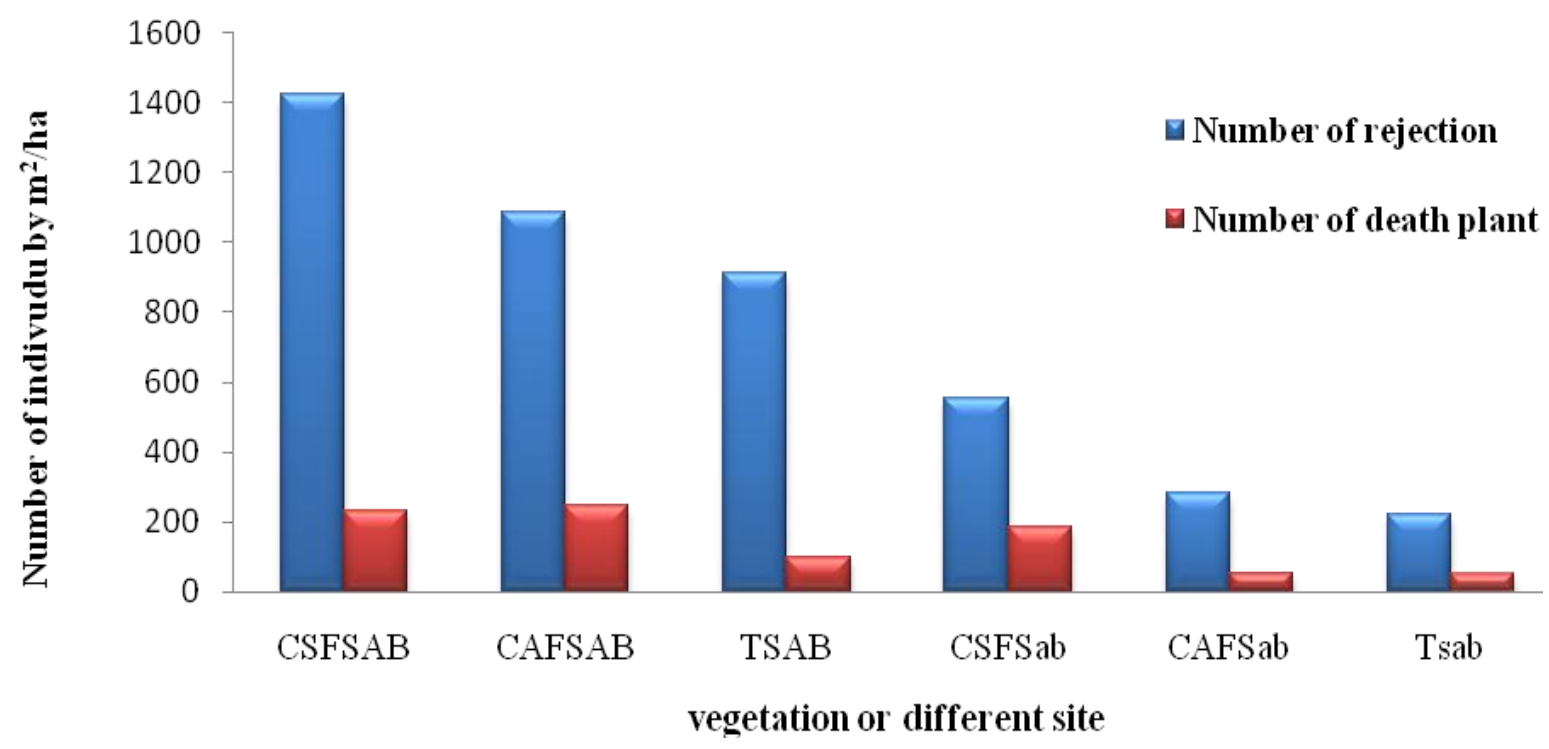

Fig. 2: Number of rejection and death plants. CSFSab $=$ cut without bushland fire; $C A F S a b=$ Cut with bushland fire; $T S A b=$ control bushland; $\mathrm{CSFSAB}=$ cut without savanna fire; $\mathrm{CAFSAB}=$ Cut with savanna fire; $\mathrm{TSAB}=$ savannah witness.

\section{Evolution of rejection and mortality of ligneous according to time and site}

Fig. 3 shows the evolution of ligneous in both savannas. This evolution shows the floristic contribution in the savanna. Before cutting (December), 05 species in CSF and $\mathrm{CAF}$ and 04 in the control site were identified in the shrubby savanna. The regeneration began in January with 04 species for the CSF, with an evolution of 05 species in March. The number of species increased from May (06) to August (07) species. For the CAF site, the number of species ranges from 05 in March to 06 in April. In control site the number of species decrease from March to April with respectively (02) and (01) species and this number increased from May to August (06) species. This drop can be explained by the drying of shrubs root with sun, low humidity and overgrazing.

Before cutting and bush fire the trees savanna, the number of species in the CSF, CAF and control was 17, 15 and 14 respectively. After cutting there was a drop in the number of species and evolution of species in CSF and CAF. In the CSF site there was a variation of species ranging from 13 (January) 20 (August), 13 (January) an 18 (August) in the CAF. In the control site this evolution of the species depends of months. This evolution decreased in February with 06 species and increased from April (15) to June (25) then felt during the last two months with 14 species. This evolution suggests the abundance of trees and shrubs.

\section{Regeneration rate of species in the two savannas}

The rate of regeneration after cutting changed according to species by site and depending on the setting applied to the vegetation. Fig. 4 shows that in the shrubby savanna, the regeneration rate is $84.18 \%$ in CAF site, $81.38 \%$ in control site and $74.76 \%$ in CSF. In tree savanna this regeneration rate is $90.22 \%$ in control site, $85.97 \%$ in CSF and 81.41 in CAF site. This variation may be due to quick regeneration of certain species such as: Piliostigma thonningii, Hymenocardia acida, Syzygium guineense var. macrocarpum. 


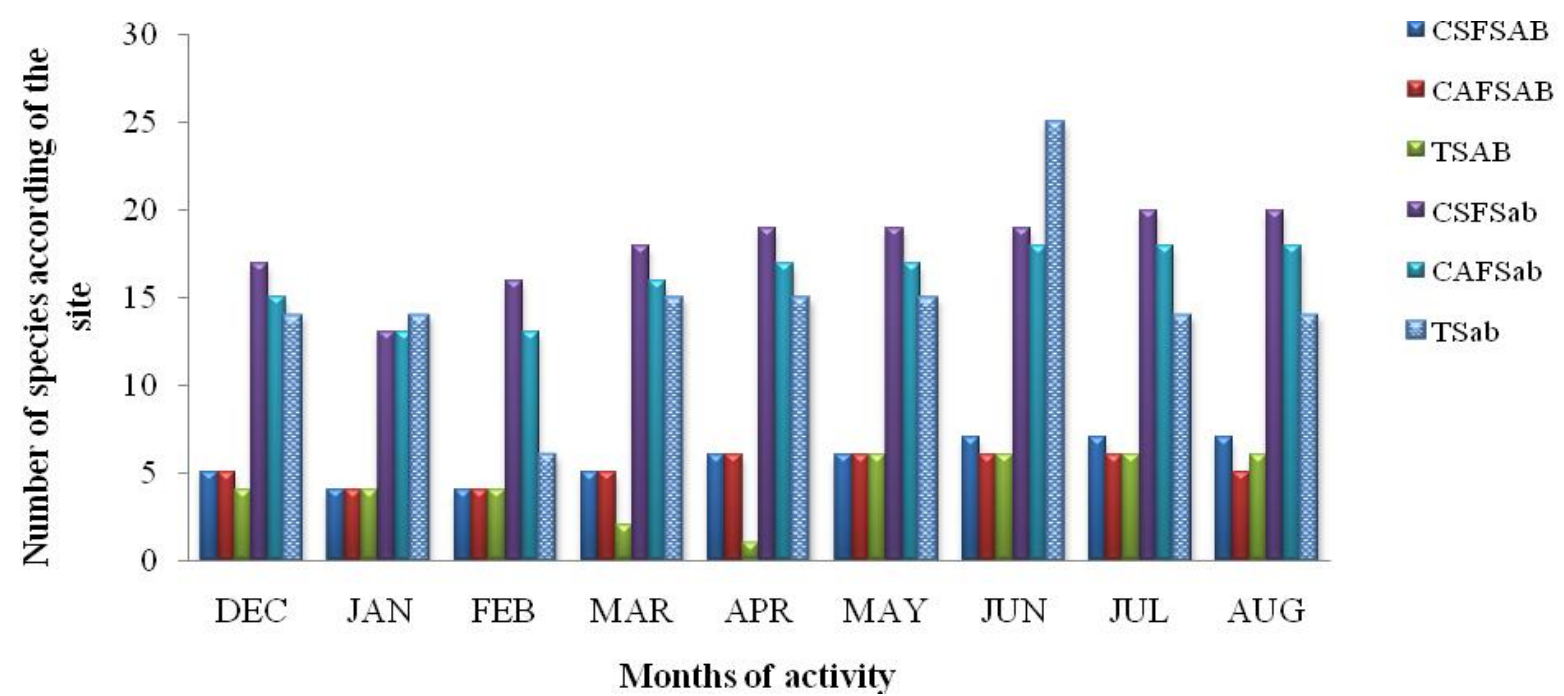

Fig. 3: Number of ligneous by month and site. CSFSab = cut without bushland fire; CAFSab = Cut with bushland fire; TSAb = control bushland; CSFSAB = cut without savanna fire; CAFSAB = Cut with savanna fire; TSAB = savannah witness.

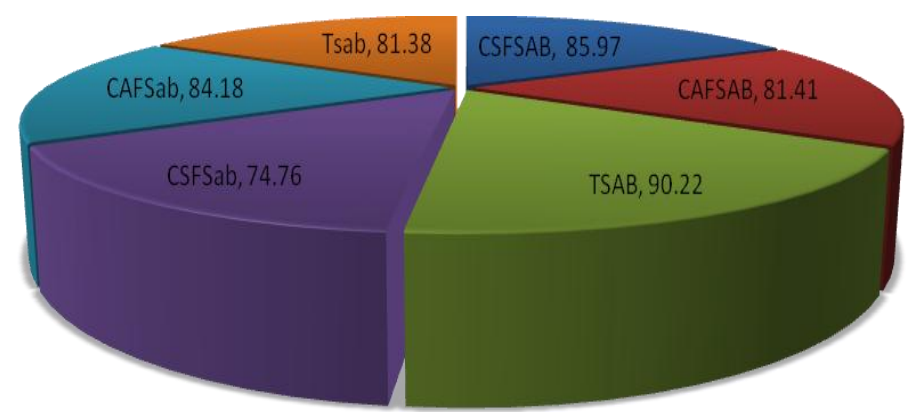

Fig. 4: Rate regeneration of species. CSFSab $=$ coupe sans feu savane arbustive; CSFSab = cut without bushland fire; $\mathrm{CAFSab}=$ Cut with bushland fire; TSAb = control bushland; CSFSAB $=$ cut without savanna fire; CAFSAB $=$ Cut with savanna fire; TSAB = savannah witness.

\section{Mortality rate of ligneous}

Fig. 5 shows that, in the shrubby savanna, mortality rate of ligneous was $25.24 \%$ for CSF site, $18.82 \%$ for CAF and $18.62 \%$ for the control site. However in the tree savanna this mortality rate was $18.59 \%$ in CAF site, $14.03 \%$ in CSF and $9.78 \%$ in the control site. The mortality rate was higher in the shrubby savanna because of degraded area through breeding, animals grazing and trample young rejection of certain species like Piliostigma thonningii, Hymenocardia acida, Syzygium guineense var. macrocarpum, Entada africana, Maesa lenceolata, Cinera glomeratum, albizia zygia, Fagara senegalensis, Bridelia ferruginea, Vitex doniana, Terminalia glaucescens, Heeria pulcherima.

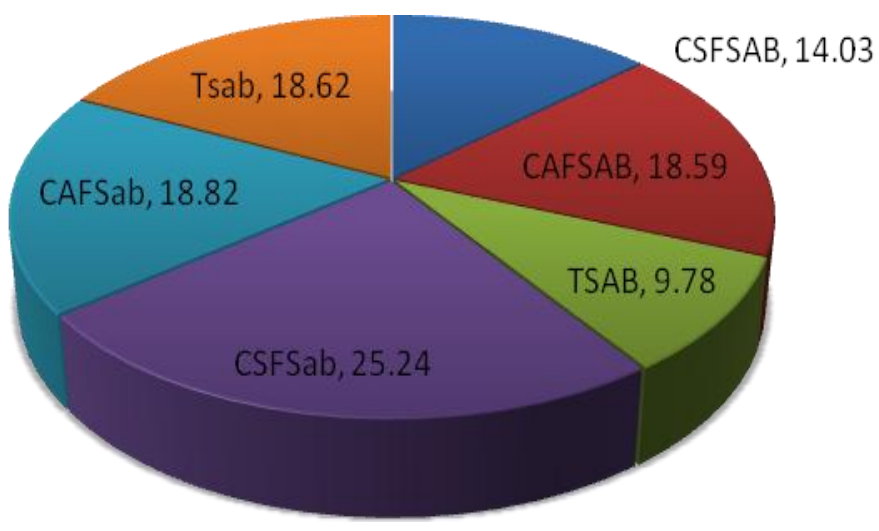

Fig. 5: Mortality rate (\%).CSFSab = cut without bushland fire; $\mathrm{CAFSab}=$ Cut with bushland fire; TSAb = control bushland; CSFSAB = cut without savanna fire; CAFSAB = Cut with savanna fire; TSAB = savannah witness.

\section{Regeneration of ligneous depending on the savanna}

Analyses of variance of quantity (site) shows that these factors (frequency) have significant effect at with a probability of 0.0010 (Table 3). The homogeneity test showed that there was no significant $(p \geq 0.05)$ difference between different types of vegetation. Species that had a high average and standard deviation of rejection were:

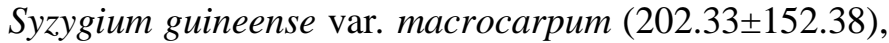
Harungana madagascariensis $(169 \pm 44.03)$ and Hymenocardia acida (113.6 \pm 132.82$)$. Those that had a small regeneration and endangered were: Gardenia aquala (1 \pm 00$)$, Ficus vogelii $(2 \pm 0.00)$ and Ficus glumosa $(3 \pm 0.00)$. 
Table 3. Regeneration of species according to vegetation (stems).

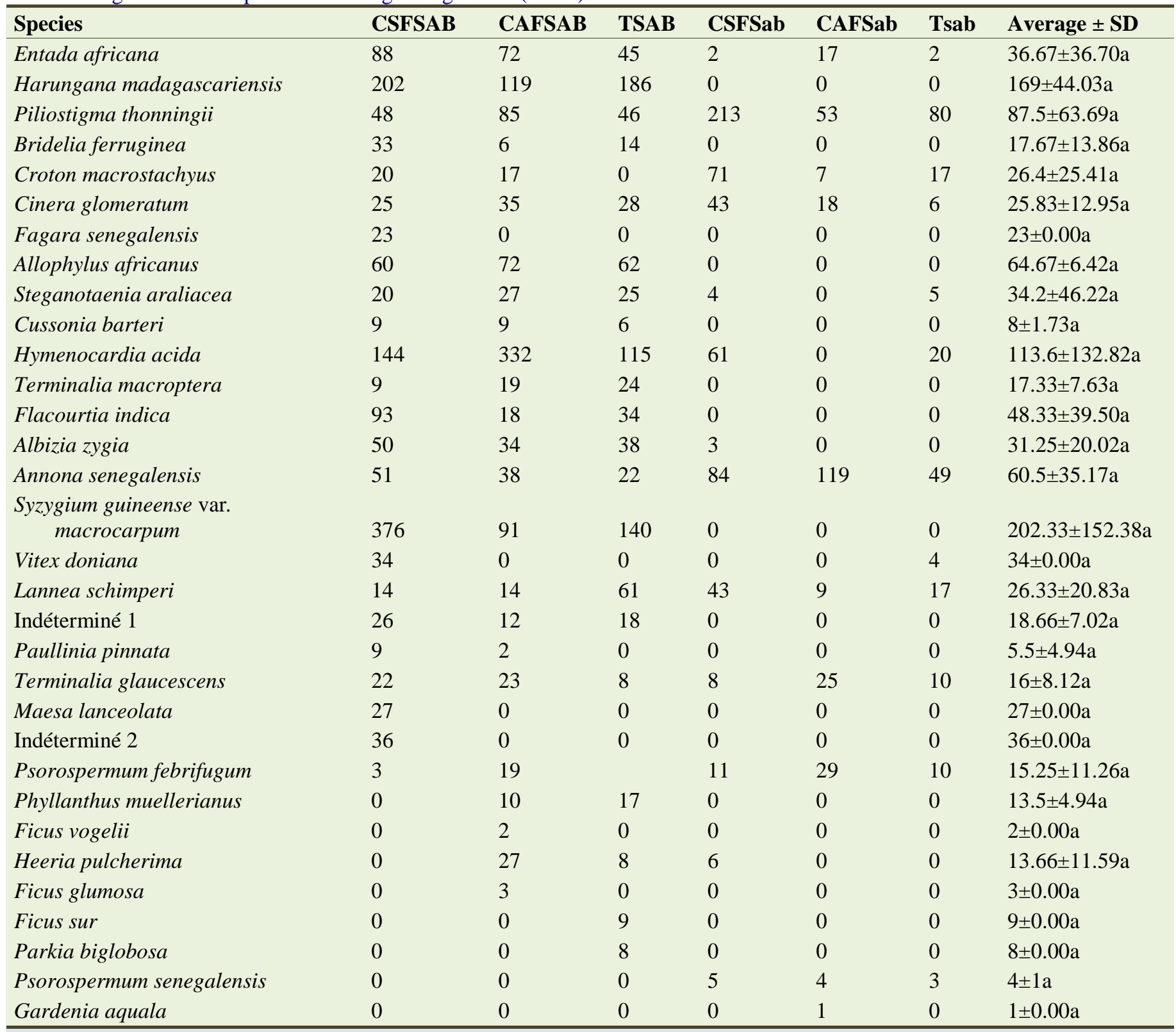

The number affected by the same letter are not significant at $0,05 \%$. CSFSab = cut without bushland fire; CAFSab $=\mathrm{Cut}$ with bushland fire; TSAb = control bushland; CSFSAB = cut without savanna fire; CAFSAB = Cut with savanna fire; TSAB = savannah witness.

\section{Mortality of species according to site}

The average mortality of species depends on their site. Species having a high number of dead plants were Syzygium guineense var. macrocarpum (30 stems), Hymenocardia acida (29 stems) and Piliostigma thonningii (27 stems).

Impact of wood cut and bush fire on the mode of dispersal of diaspore species

Table 5 shows the different method of dispersal. This mode of dissemination changes according to species and site. According to this table Anemochory has a high rate of dispersal in both savannas. Shrubby savanna and tree savanna with $26.36 \%$ and $34.45 \%$ respectively have almost the same rate of dispersal of diaspores. The second mode is Zoochory with $24.03 \%$ in shrubby savanna and $19.45 \%$ tree savanna. Hydrochory and Autochory are the dispersal methods that have low percentages with respectively $13.96 \%$ and $13.18 \%$, in shrubby savanna, $19.44 \%$ and $6.67 \%$ in tree savanna. 
Table 4. Mortality of species based on treatment (stems).

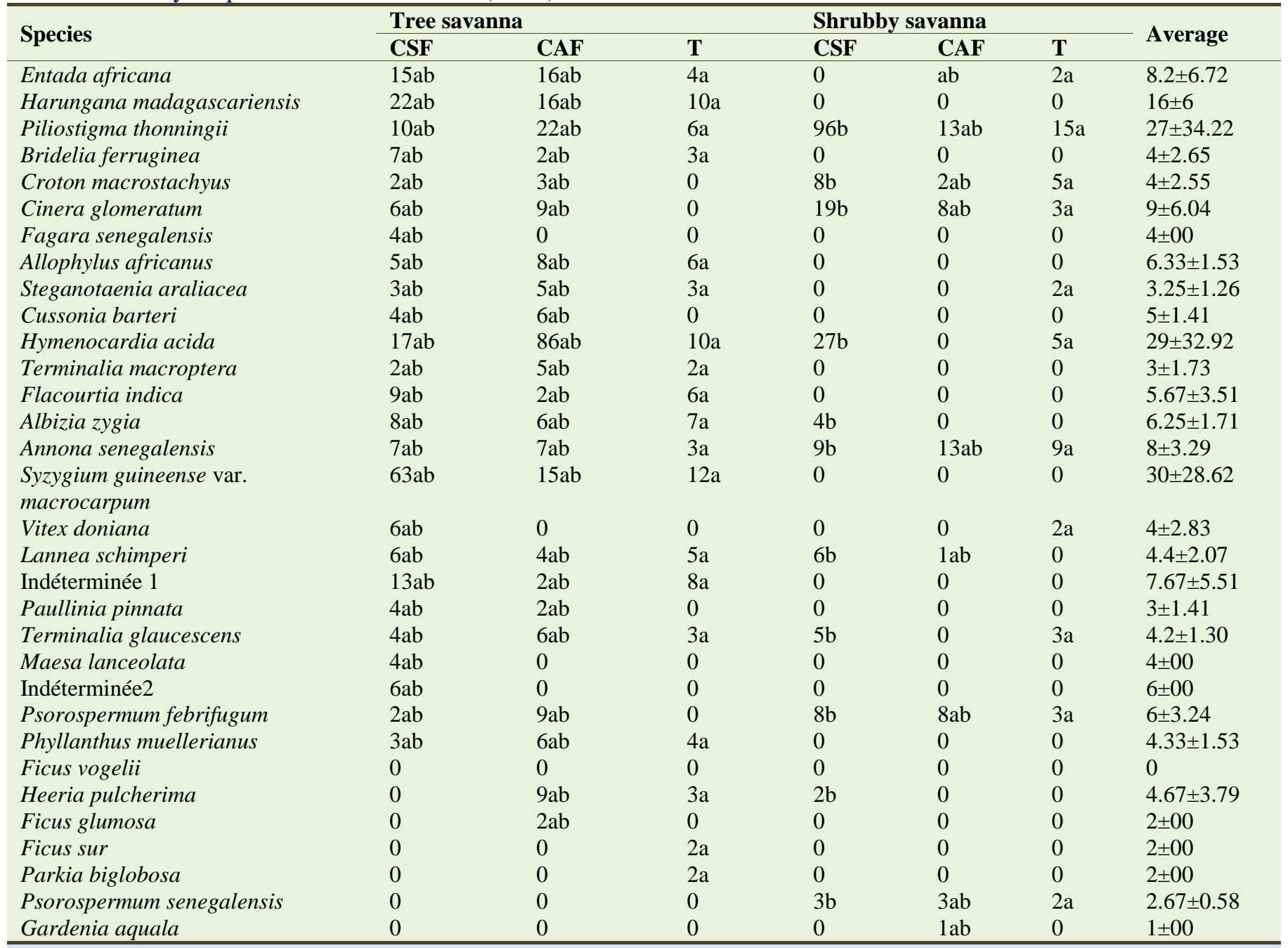

A number affected by the same letter are not significant at $0.05 \%$. CSFSab $=$ cut without bushland fire; CAFSab $=$ Cut with bushland fire; $\mathrm{TSAb}=$ control bushland; CSFSAB = cut without savanna fire; CAFSAB $=$ Cut with savanna fire; $\mathrm{TSAB}=$ savannah witness.

Table 5. Dissemination of species in savanna (\%).

\begin{tabular}{|c|c|c|c|c|c|c|c|c|}
\hline \multicolumn{2}{|c|}{ Method or mode of dissemination } & \multirow{2}{*}{$\begin{array}{l}\text { CSFSab } \\
0.78\end{array}$} & \multirow{2}{*}{$\begin{array}{l}\text { CAFSab } \\
0\end{array}$} & \multirow{2}{*}{$\begin{array}{l}\text { Tsab } \\
0.78\end{array}$} & \multirow{2}{*}{$\begin{array}{l}\text { CSFSAB } \\
1.11\end{array}$} & \multirow{2}{*}{$\begin{array}{l}\text { CAFSAB } \\
1.11\end{array}$} & \multirow{2}{*}{$\begin{array}{l}\text { TSAB } \\
1.11\end{array}$} & \multirow{2}{*}{$\begin{array}{l}\text { Average } \\
0.81 \pm 0.43 \mathrm{a}\end{array}$} \\
\hline Hydrochory & Pleo & & & & & & & \\
\hline & Sarc & 1.55 & 0.78 & 1.55 & 0.56 & 0 & 0.56 & $0.83 \pm 0.61 \mathrm{a}$ \\
\hline & Sler & 0 & 0 & 0 & 1.11 & 1.11 & 1.11 & $0.56 \pm 0.61 \mathrm{a}$ \\
\hline & Naut & 2.33 & 1.55 & 1.55 & 3.33 & 2.78 & 2.78 & $2.39 \pm 0.72 \mathrm{a}$ \\
\hline \multirow[t]{2}{*}{ Zoochory } & Epiz & 2.33 & 2.33 & 2.33 & 2.22 & 2.78 & 1.67 & $2.27 \pm 0.36 \mathrm{a}$ \\
\hline & Endo & 1.55 & 1.55 & 1.55 & 1.11 & 0.56 & 1.11 & $1.24 \pm 0.40 \mathrm{a}$ \\
\hline \multirow[t]{3}{*}{ Anemochory } & Anem & 10.08 & 6.98 & 4.65 & 8.33 & 8.89 & 6.11 & $7.51 \pm 1.98 \mathrm{a}$ \\
\hline & Ptér & 0.78 & 0.78 & 0 & 1.11 & 1.67 & 2.78 & $1.18 \pm 0.95 \mathrm{a}$ \\
\hline & Pogo & 1.55 & 0.78 & 0.78 & 1.11 & 1.67 & 2.78 & $1.44 \pm 0.75 \mathrm{a}$ \\
\hline Autochory & Ball & 4.65 & 4.65 & 3.88 & 2.22 & 2.22 & 2.22 & $3.31 \pm 1.22 \mathrm{a}$ \\
\hline
\end{tabular}




\section{Effect of wood cut and bush fire on the regeneration}

Evolution of the regeneration of some wood cut consumed by livestock affect their growth. The sew rejection consumed by the cattle is due to the lack of fodder during certain season (February, March, April) and specially after bush fire some species branch after cutting wood, these species are: : Syzygium guineense var. macrocarpum, Hymenocardia acida, Piliostigma thonningii and Terminalia glaucescens.

\section{Vertical structure of ligneous in tree savanna}

Fig. 6 shows that in tree savanna, Maesa lanceolata $(151 \mathrm{~cm})$, Annona senegalensis $(144 \mathrm{~cm})$ and Entada africana $(137 \mathrm{~cm})$ are the species that have a very higher height Cussonia barteri $(14 \mathrm{~cm})$, Lannea schimperi $(18 \mathrm{~cm})$ and Terminalia macroptera $(22 \mathrm{~cm})$ are the species that have low height in CSF. In the CAF site, Phyllanthus muellerianus $(135 \mathrm{~cm})$, Annona senegalensis $(120 \mathrm{~cm})$ and Croton macrostaschyus $(106 \mathrm{~cm})$ are the species that growth quickly. In the control sites Annona senegalensis $(135 \mathrm{~cm}), \quad$ Phyllanthus muellerianus $(130 \mathrm{~cm})$ and Allophylus afrianus $(128 \mathrm{~cm})$ are very high than Cussonia barteri $(24 \mathrm{~cm})$, Lannea schimperi $(28 \mathrm{~cm})$ and Terminalia glaucescens $(31 \mathrm{~cm})$.The small changes in the size of species in CAF may be due to the action of fire that slows the growth of species. Higher growth of species such as (Piliostigma thonningii, Psorospermum febrifugum and Cinera glomeratum) in the CAF can be explained by the action of bush fire that accelerates the growth of other species.

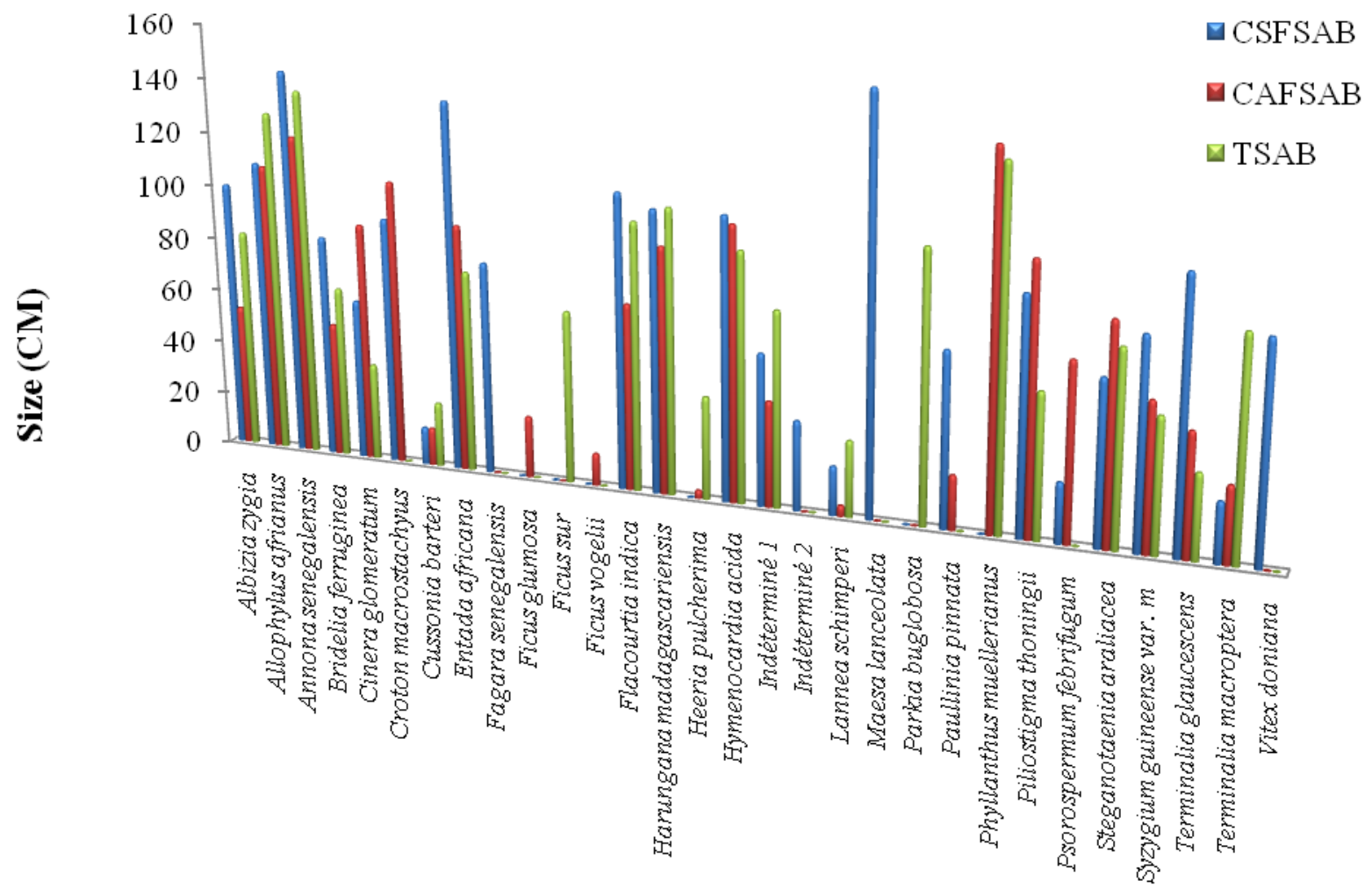

\section{Species}

Fig. 6: Evolution of the size of ligneous in tree savanna during 09 month. CSFSab = cut without bushland fire; $\mathrm{CAFSAB}=$ Cut with savanna fire; TSAB $=$ savannah witness.

\section{Evolution of size of ligneous in shrubby savanna}

Fig. 7 shows the evolution of ligneous in the shrubby savanna. According to this figure: Piliostigma thonningii $(113 \mathrm{~cm})$, Croton macrostachyus $(106 \mathrm{~cm})$ and Cineran glomeratum $(80 \mathrm{~cm})$ have a high evolution size while Albizia zygia $(01 \mathrm{~cm})$, Entada africana $(02 \mathrm{~cm})$ and
Steganotaenia araliacea $(12 \mathrm{~cm})$ are the species that have low size in CSF. In CAF Annona senegalensis $(130 \mathrm{~cm})$, Entada africana $(99 \mathrm{~cm})$ and Piliostigma thonningii $(77 \mathrm{~cm})$ have a higher size than Gardenia aquala $(01 \mathrm{~cm})$, Lannea schimperi $(17 \mathrm{~cm})$ and Psorospermum senegalensis $(26 \mathrm{~cm})$. In the control site Hymenocardia acida $(94 \mathrm{~cm})$, Piliostigma thonningii $(92 \mathrm{~cm})$ and Annona senegalensis 
$(52 \mathrm{~cm})$ are species that have a higher size and Lannea schimperi $(05 \mathrm{~cm})$, Albizia zygia $(06 \mathrm{~cm})$ and Vitex doniana $(12 \mathrm{~cm})$ have the low size. In CAF, actions of bush fire decrease the growth of certain species and accelerate the growth of other species such as Entada africana, Annona senegalensis and Psorospermum febrifugum.

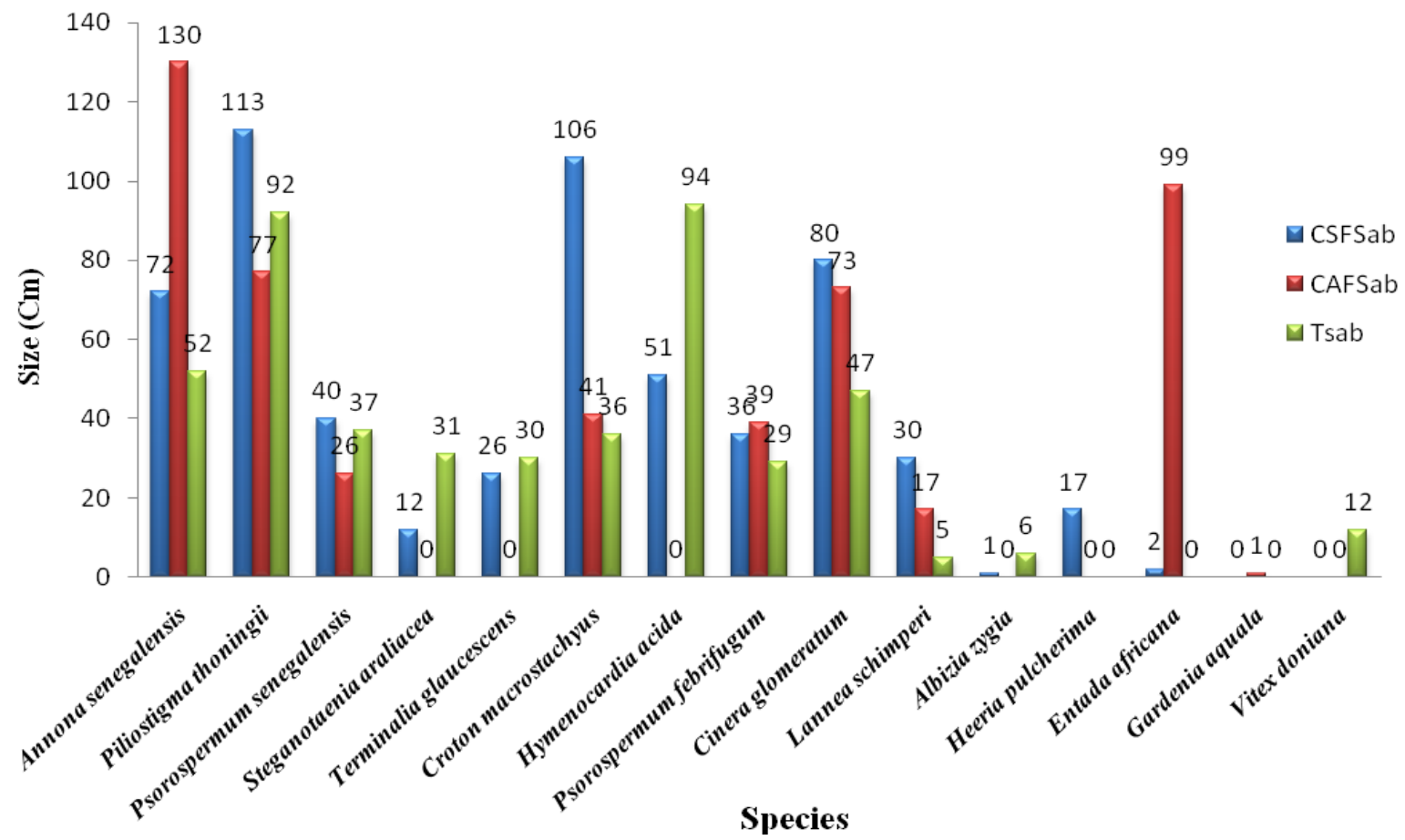

Fig. 7: Evolution of size the ligneous in shrubby savanna. CSFSab = cut without bushland fire; CAFSAB = Cut with savanna fire; TSAB = savannah witness.

\section{Evolution of ligneous number per month and side}

Fig. 8 shows evolution of ligneous in woody vegetation per month and site and this evolution show their floristic contribution in savanna. Before cutting (December) 05 species in CSF and CAF, 04 species in the control site were identified in shrubby savanna. Regeneration begging in January and February with 04 species in CSF site, the evolution was 07 in March, 06 in April and May; 07species from June to August in CAF, the evolution is 05 in March, 06 from April to July and 05 species in August. For control site, the number of species decrease in March and April with respectively (02) and (01) species and increase from May to August with (06) species. This drop of species may be due to drying of roots, deficiency of moisture and overgrazing. In the tree savanna before cutting and fire, the number of species in CSF, CAF and control site were 17, 15 and 14 respectively. After cutting there was a drop of species then an increase of species in CSF and CAF sites. Variation of species number were 12 in (January), 20 (August) in CSF and 13 in January and 18 in August in the CAF site. However, in the control site, the number of species depends on months. This number decreased, with
06 species in February and increased from April (15) to June (25), then decreased against during the last two months with 14 species. This evolution is due to the abundance of trees and shrubs.

\section{Consolidation or regrouping of the number of ligneous according to the botanical family of two savannas}

Thirty two (32) species in tree and shrubby savanna is classified in 19 families (Fig. 9). Tree savanna has 30 species classified in 18 families. Euphorbiaceae and Mimosaceae have 04 species with a percentage of $13.79 \%$ followed by Moraceae with 03 species $(10.34 \%)$. The family with 01 and 02 species has respectively $3.45 \%$ and $6.90 \%$ which contribute greatly to the floristic richness of ligneous in tree savanna. Therefore in the shrubby savanna we have 15 species regrouped in 11 families. Shrubby savanna is dominate by Mimosaceae with 03 species (20\%) followed by Anacardiaceae and Clusiaceae that has 02 species $(13.33 \%)$. The family having 01 and 02 species is represented respectively with $46.66 \%$ and $53.34 \%$. This can be explained by the dominance of tree and shrubs in tree savanna. 


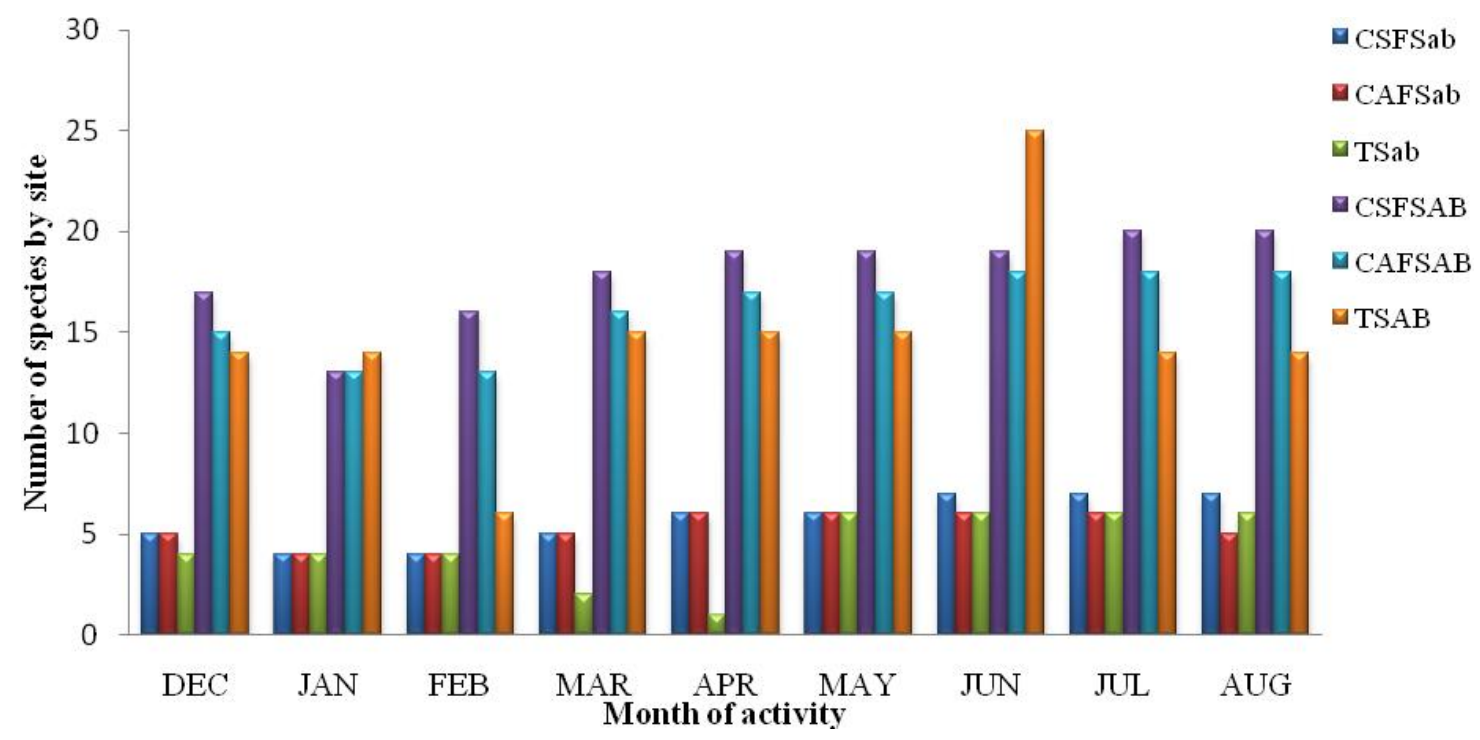

Fig. 8: Number of ligneous by month and site.

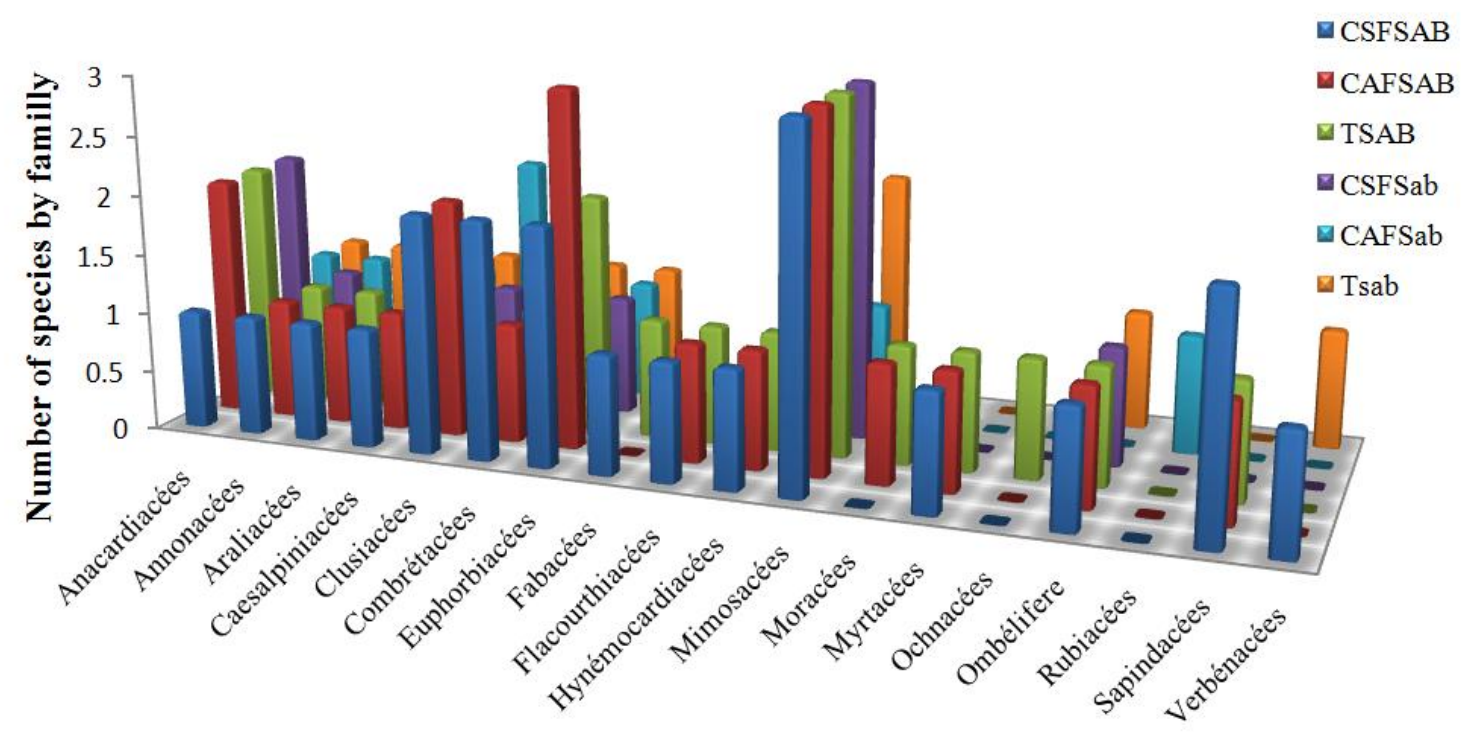

Fig. 9: Grouping of ligneous by family.

Grouping or consolidation of ligneous by botanical families according to vegetation

Fig. 10 shows the grouping of ligneous based on their families. In the tree savanna, the Mimosaceae (03 species) and Euphorbiaceae (03 species) are mostly represented. Mimosaceae are represented with $14,29 \%$ in CSF, $15 \%$ in CAF, and control site. However, Euphorbiaceae are represented with $15 \%$ in CAF, $10 \%$ in control site and $9.52 \%$ in CSF. In the shrubby savanna, Mimosaceae are mostly represented in CSF (25\%), $16.18 \%$ in control and $12.50 \%$ in CAF site followed by Clusiaceae with respectively $25 \%$ in CAF 9.09 in control site and $8.33 \%$ in CSF. In fact, on the 19 families registered over half are represented by only one species.

\section{Index of floristic diversity}

Species richness of vegetation varied from 10 to 13 species in the shrubby savanna and from 21 to 24 species in the tree savanna. Table 6 shows the variation of Shannon index from 2.53 to 2.80 with a Pielou fairness of 0.30 to 0.36 in the shrubby savanna. However, in the tree savanna, Shannon index is from 3.61 to 3.75 with Pielou fairness of 0.36 to 0.38 . The low richness, index and Pielou fairness of certain sites may be due to wood cut, bush fire and livestock activities that cause the disappearance of some species. 


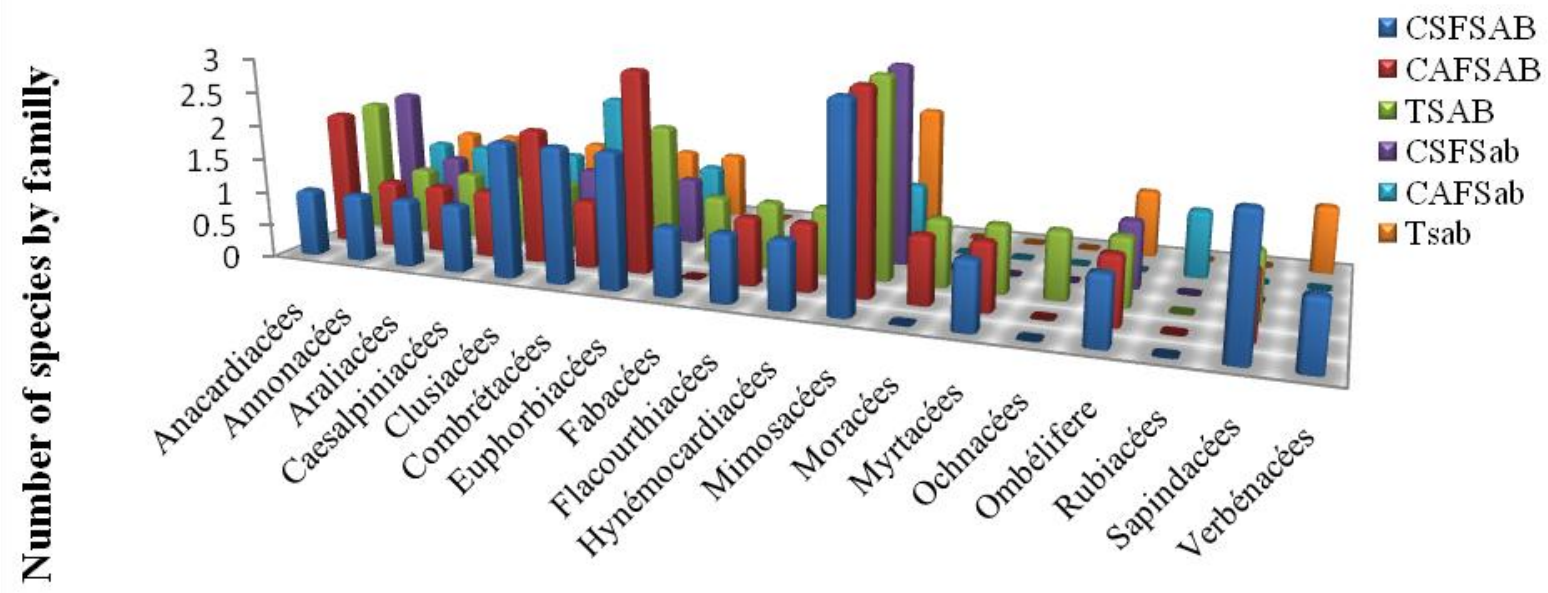

Fig. 10: grouping of ligneous number per family and site.

Table 6. Species richness, Shannon index and Pielou fairness of site.

\begin{tabular}{lllllll}
\hline Diversity index & CSFSAB & CAFSAB & TSAB & CSFSab & CAFSab & Tsab \\
\hline Species richness (SR) & 24 & 24 & 21 & 13 & 10 & 12 \\
Shannon index (SI) & 3.74 & 3.61 & 3.75 & 2.70 & 2.53 & 2.80 \\
Piélou equitability (EQ) & 0.36 & 0.36 & 0.38 & 0.30 & 0.31 & 0.36 \\
\hline
\end{tabular}

$\mathrm{CSFSab}=$ cut without bushland fire; CAFSab = Cut with bushland fire; TSAb = control bushland; CSFSAB = cut without savanna fire; $\mathrm{CAFSAB}=$ Cut with savanna fire; $\mathrm{TSAB}=$ savannah witness.

Impact of wood cutting and bush fire on the ecological value of species of tree savannas

Table 7 shows the importance value, relative dominance, relative frequency and relative density of the ligneous in the tree savannas. Species that have the higher density of regeneration ranged from $6.19 \%$ to $26.44 \%$ and the importance value of $11.67 \%$ to $35.99 \%$ : Syzygium guineense var. macrocarpum, Harungana madagascariensis, Hymenocardia acida, Flacourtia indica and Entada Africana. Species with a low density range from $0.18 \%$ to $0.55 \%$ and the importance value of $3.62 \%$ to $6.36 \%$ (Psorospermum febrifugum, Ficus vogelii, Paullinia pinnata, Ficus glumosa and Bridelia ferruginea).

Table 7. Relative density, relative frequency, relative dominance and importance value of regeneration of tree savannas.

\begin{tabular}{|c|c|c|c|c|c|c|c|c|c|c|c|c|}
\hline \multirow{2}{*}{ Scientific name } & \multicolumn{4}{|l|}{ CSF } & \multicolumn{4}{|l|}{ CAF } & \multicolumn{4}{|l|}{ ST } \\
\hline & Dre & Fre & Dore & IV & Dre & Fre & Dore & IV & Dre & Fre & Dore & IV \\
\hline $\begin{array}{l}\text { Harungana } \\
\quad \text { madagascariensis }\end{array}$ & 14.21 & 4.52 & 2.16 & 20.89 & 10.96 & 4.19 & 0.54 & 15.69 & 0.20 & 4.4 & 0.56 & 5.16 \\
\hline Piliostigma thonningii & 3.38 & 4.52 & 3.56 & 11.46 & 7.83 & 4.79 & 3.46 & 16.08 & 8.93 & 5.03 & 2.51 & 16.47 \\
\hline Bridelia ferruginea & 2.32 & 2.84 & 6.35 & 11.51 & 0.55 & 2.99 & 2.82 & 6.36 & 2.80 & 3.14 & 1.32 & 7.26 \\
\hline Croton macrostachyus & 1.41 & 3.95 & 12.34 & 17.70 & 1.57 & 4.19 & 17.3 & 23.07 & 0.97 & 5.03 & 26.3 & 32.31 \\
\hline Allophylus africanus & 4.22 & 4.52 & 5.36 & 14.10 & 6.63 & 4.79 & 3.75 & 15.17 & 6.78 & 5.03 & 6.52 & 18.33 \\
\hline Steganotaenia araliacea & 1.41 & 3.95 & 5.99 & 11.35 & 2.49 & 4.19 & 1 & 7.68 & 2.73 & 4.4 & 2.37 & 9.50 \\
\hline Cussonia barteri & 0.63 & 3.39 & 2.63 & 6.65 & 0.83 & 3.6 & 0.86 & 5.29 & 0.65 & 3.77 & 0 & 4.42 \\
\hline Hymenocardia acida & 10.13 & 4.52 & 3.8 & 18.45 & 30.57 & 4.79 & 2.99 & 38.35 & 14.56 & 5.03 & 3.25 & 22.84 \\
\hline Terminalia macroptera & 0.63 & 4.52 & 5.83 & 10.98 & 1.75 & 4.79 & 7.07 & 13.61 & 2.62 & 4.4 & 0.94 & 7.96 \\
\hline Flacourtia indica & 6.54 & 3.39 & 8.27 & 18.20 & 1.66 & 3.6 & 1.57 & 6.83 & 3.71 & 4.4 & 6.33 & 14.44 \\
\hline Vitex doniana & 2.39 & 4.52 & 2.2 & 9.11 & - & 0 & 0 & - & - & 0 & 0 & - \\
\hline Lannea schimperi & 0.98 & 3.95 & 0.93 & 5.86 & 1.29 & 4.19 & 0 & 5.48 & 6.67 & 4.4 & 0.94 & 12.01 \\
\hline
\end{tabular}




\begin{tabular}{|c|c|c|c|c|c|c|c|c|c|c|c|c|}
\hline \multirow{2}{*}{ Scientific name } & \multicolumn{4}{|l|}{ CSF } & \multicolumn{4}{|l|}{ CAF } & \multicolumn{4}{|l|}{ ST } \\
\hline & Dre & Fre & Dore & IV & Dre & Fre & Dore & IV & Dre & Fre & Dore & IV \\
\hline Indéterminé 1 & 1.83 & 4.52 & 1.82 & 8.17 & 1.10 & 1.79 & 0.08 & 2.97 & 1.96 & 2.53 & 2.49 & 6.98 \\
\hline Paullinia pinnata & 0.63 & 4.52 & 0.03 & 5.18 & 0.18 & 4.19 & 0 & 4.37 & - & 0 & 0 & - \\
\hline Terminalia glaucescens & 1.55 & 3.95 & 8.68 & 14.18 & 2.12 & 4.79 & 1.79 & 8.70 & 0.84 & 3.77 & 0.09 & 4.70 \\
\hline Maesa lanceolata & 1.90 & 4.52 & 2.17 & 8.50 & - & 0 & 0 & - & - & 0 & 0 & - \\
\hline Indéterminé 2 & 2.53 & 4.52 & 0 & 7.05 & - & 0 & 0.13 & 0.13 & - & 0 & 0 & - \\
\hline Psorospermum febrifugum & 0.21 & 3.39 & 0.02 & 3.62 & 1.75 & 3.6 & 0.36 & 5.71 & - & 0 & 0 & - \\
\hline Phyllanthus muellerianus & - & 0 & 0 & - & 0.92 & 3.6 & 6.87 & 11.39 & 6.75 & 5.03 & 5.81 & 17.59 \\
\hline Ficus vogelii & - & 0 & 0 & - & 0.18 & 4.19 & 0.01 & 4.38 & - & 0 & 0 & - \\
\hline Heeria pulcherima & - & 0 & 0 & - & 2.49 & 4.19 & 0.13 & 6.81 & 0.87 & 3.77 & 1.38 & 6.02 \\
\hline Ficus glumosa & - & 0 & 0 & - & 0.28 & 3.6 & 36.9 & 40.81 & - & 0 & 0 & - \\
\hline Ficus sur & - & 0 & 0 & - & - & 0 & 0 & - & 0.98 & 5.05 & 11.1 & 17.10 \\
\hline Parkia buglobosa & - & 0 & 0 & - & - & 0 & 0 & - & 0.88 & 5.03 & 4.92 & 10.83 \\
\hline TOTAL & 100.00 & 99.99 & 100.1 & 300.00 & 100.00 & 100 & 100 & 300.01 & 99.16 & 100 & 100 & 299.15 \\
\hline
\end{tabular}

$\mathrm{CSF}=$ coupe sans feu; $\mathrm{CAF}=$ coupe avec feu; Dre = relative density; Fre $=$ relative frequency; Dore $=$ relative dominance and $\mathrm{IV}=\mathrm{importance}$ value.

Impact of wood cut and bush fire on the ecological value of species in the shrubby savanna

Species that have a higher relative density of regeneration were: Annona senegalensis (42.20\%),
Piliostigma thonningii (38.44\%), Croton macrostachyus $(12.82 \%)$. Species that have the low density $0.35 \%$ (Gardenia aquala), $0.36 \%$ (Entada africana) and $0.54 \%$ (Albizia zygia) have a risk to disappear due to the degradation of savanna.

Table 8. Relative density, relative frequency, relative dominance and importance value of regeneration of shrubby savanna.

\begin{tabular}{|c|c|c|c|c|c|c|c|c|c|c|c|c|}
\hline \multirow{2}{*}{ Scientific name } & \multicolumn{4}{|l|}{ CSF } & \multicolumn{4}{|l|}{ CAF } & \multicolumn{4}{|l|}{ ST } \\
\hline & Dre & Fre & Dore & IV & Dre & Fre & Dore & IV & Dre & Fre & Dore & IV \\
\hline Piliostigma thonningii & 38.44 & 10.38 & 4.99 & 53.81 & 18.79 & 12.91 & 12.69 & 44.40 & 35.87 & 11.11 & 15.51 & 62.49 \\
\hline Steganotaenia araliacea & 0.73 & 5.20 & 0.11 & 6.04 & - & - & - & - & 2.24 & 11.11 & 19.35 & 32.71 \\
\hline Terminalia glaucescens & 1.44 & 7.80 & 61.45 & 70.69 & 8.87 & - & - & 8.87 & 4.48 & 6.35 & - & 10.83 \\
\hline Croton macrostachyus & 12.82 & 10.38 & 17.10 & 40.30 & 2.48 & 11.29 & 14.49 & 28.26 & 7.62 & 9.53 & 1.12 & 18.27 \\
\hline Cinera glomeratum & 7.67 & 10.38 & 0.57 & 18.62 & 6.38 & 12.91 & 4.37 & 23.66 & 2.69 & 11.11 & 4.47 & 18.27 \\
\hline Lannea schimperi & 7.67 & 7.80 & - & 15.47 & 3.19 & 9.67 & 1.31 & 14.17 & 7.62 & 6.35 & - & 13.97 \\
\hline Albizia zygia & 0.54 & 6.50 & 0.04 & 7.08 & - & - & - & - & - & - & - & - \\
\hline Heeria pulcherima & 1.09 & 6.50 & 0.04 & 7.63 & - & - & - & - & - & - & - & - \\
\hline Entada africana & 0.36 & 5.20 & - & 5.56 & 6.05 & 12.91 & 8.97 & 27.93 & 0.90 & 1.57 & - & 2.47 \\
\hline Gardenia aquala & 0 & - & - & - & 0.35 & 6.44 & 0.27 & 7.06 & - & - & - & - \\
\hline
\end{tabular}

$\mathrm{CSF}=$ cut without fire $\mathrm{CAF}=\mathrm{Cut}$ with fire; Dre = relative density; Fre = relative frequency; Dore $=$ relative dominance and IV = importance value.

\section{Dispersion of ligneous in both savannas}

ACP (Principal Component Analysis) was made by the slip of species in the both savannas (tree and shrubby) was used to represent the characteristics of ligneous in different savannas according to their presence and site. Representation of data and species on the factorial plane of axe 1 and 2 allows to group ligneous that have similar characteristics. Figure 11 shows three figures $(a, b, c)$ having on the three axes: F1; F2; F1 and F2 the following values $47.05 \%, \quad 36.90 \%$ and $83.85 \%$ respectively.
Fig.11a shows that there is a positive correlation between CSFSAB, CAFSAB and TSAB. CSFAB, CAFSAB and TSAB are also positively correlated. Fig. $11 \mathrm{~b}$ shows species that are mostly and least represented in the different sites. Syzygium guineense var. macrocarpum, Harungana madagascariensis and Hymenocardia acida have a dispersion shifted from other species, justified by its abundance and high diversity in different site of tree savannah but in Shrubby savannah its Piliostigma thonningii and Annona senegalensis. Species that forming the cloud of point around the two axes are less diversified and most are uncommon in some site. 
Fig. 11c shows the correlation between the different site, vegetation and between the species that are most and least represented. Observation of the ligneous on the F1

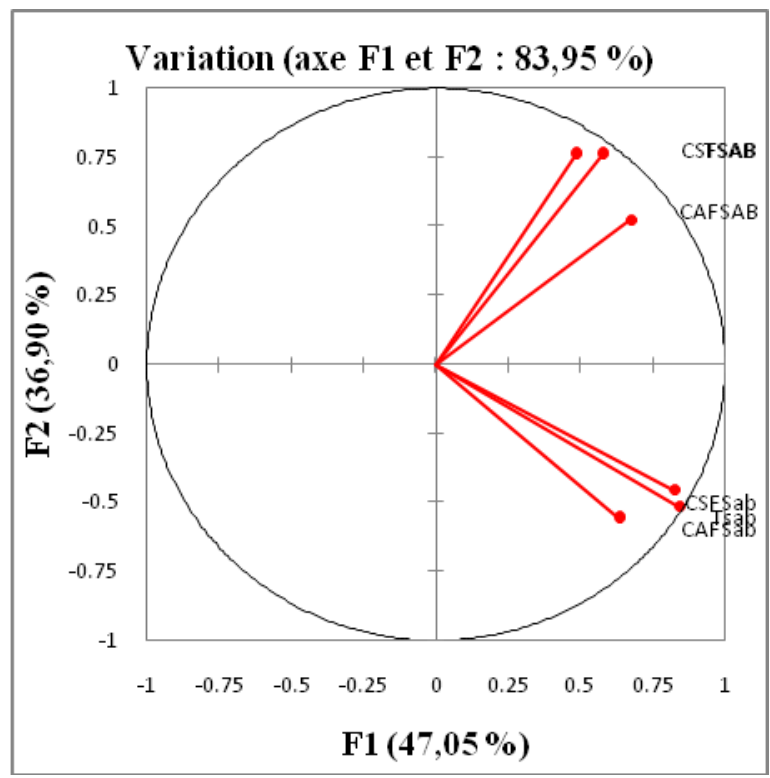

Fig. 11a: Correlation between sites. axis (vertical) and F2 (horizontal) shows that the species that are least present are on the negative side and the most present are on the positive side.

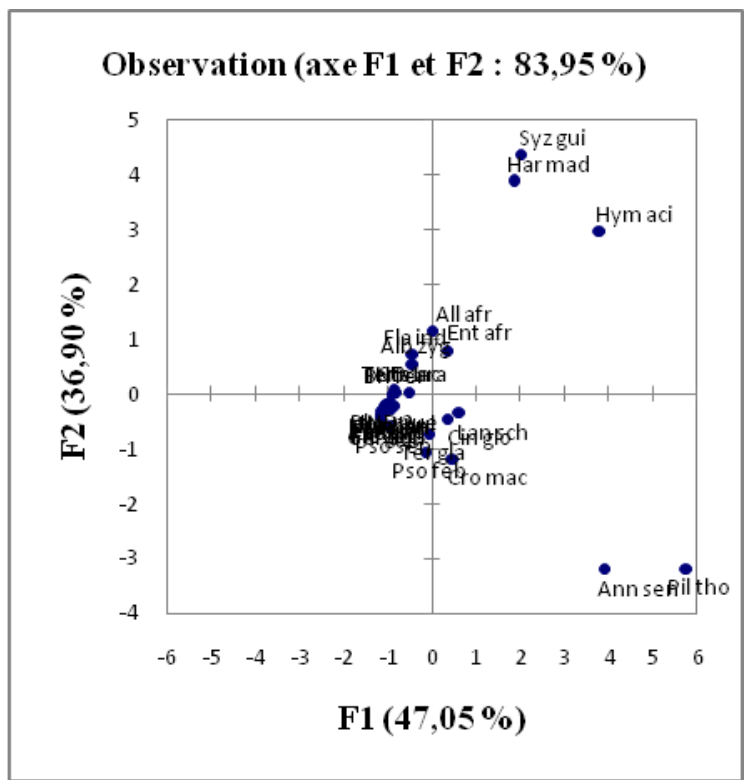

Fig. 11b: Species dispersion.

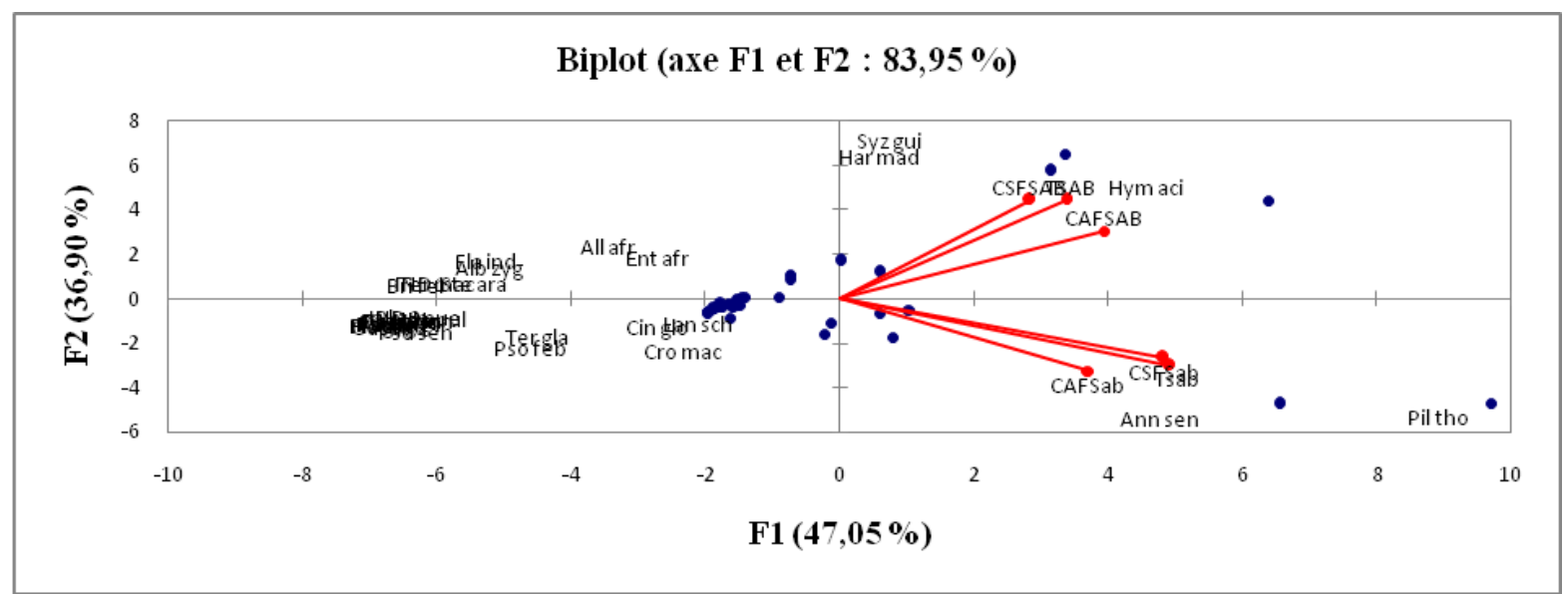

Fig. 11c: Correlation between site and species dispersal

Fig. 11: ACP of species in site of both savannas (shrubby and tree).

Impact of wood cut and bush fire on the distribution of species in the savanna

Fig. 12 shows results of the floristic homogeneity test. The study area is under the influence of wood logging by bush fire and overgrazing. In the shrubby savanna, accidental species are most represented and the distribution of species is fairly common. Accidental species are Gardenia aquala, Vitex doniana. Species that are fairly frequent are: Entada africana, Terminalia glaucescens. Frequent species are Lannea schimperi, Psorospermum senegalensis and the much frequent species are Piliostigma thonningii and Annona senegalensis (Fig. 12a). While in the tree savanna, very frequent species are numerous and the dispersal of species is accessory. Accessory species are (Ficus sur, Ficus vogelii, Parkia biglobosa) accessory are 20 to 40 (unknown species), fairly frequent 40 to 60 (Cinera glomeratum and unknown species). Frequent species are 60 to 80 (Bridelia ferruginea, Cussonia barteri and Flacourtia indica), and the much frequent 80 to 100 (Harungana madagascariensis, Hymenocardia acida and Syzygium guineense var. macrocarpum) (Fig. 12b). 


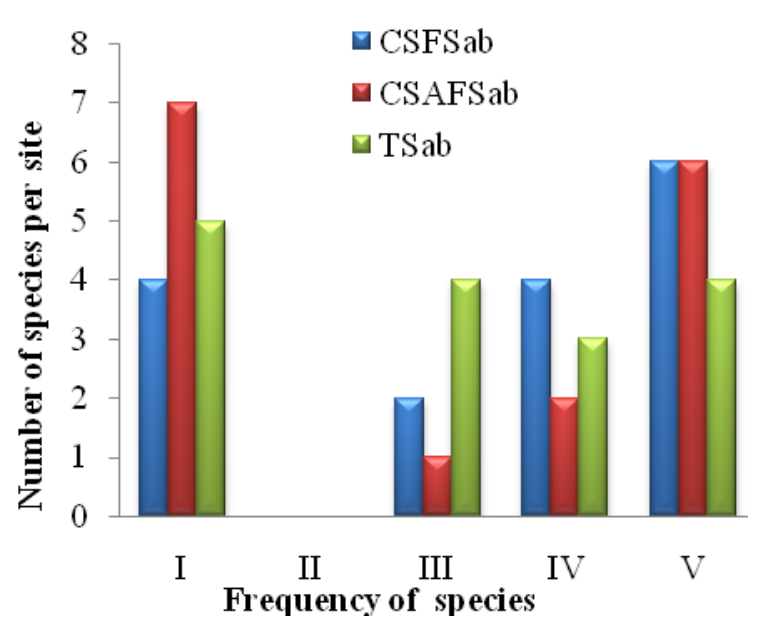

Fig. 12a: Frequency index in shrubby savanna.

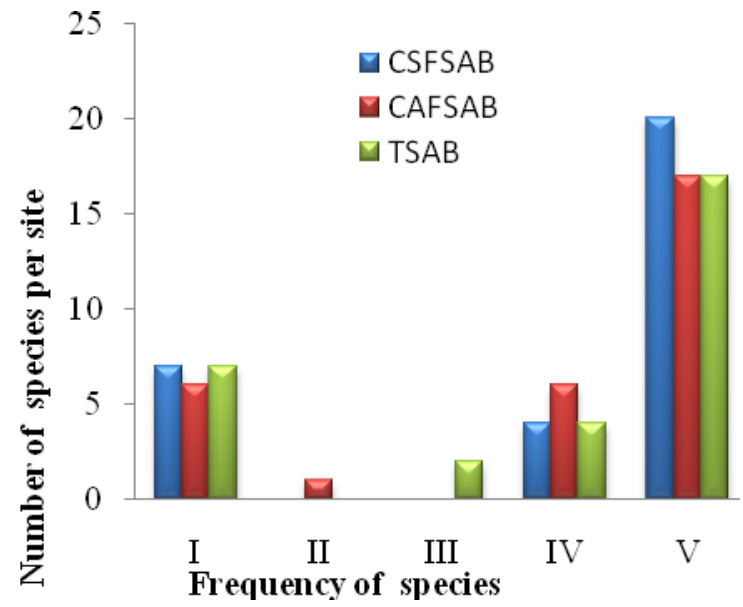

Fig. 12b: Frequency index in trees savanna.

Fig. 12: Frequency index of ligneous. CSFSab $=$ cut without bushland fire; $\mathrm{CAFSab}=\mathrm{Cut}$ with bushland fire; TSAb $=$ control bushland; CSFSAB = cut without savanna fire; CAFSAB = Cut with savanna fire; $\mathrm{TSAB}=$ savannah witness.

\section{Discussion}

Wood cuts and bush fire have an influence on the regeneration of vegetation species in the Adamawa region. This influence is noticed through the reduction of the number of woody stems. Tchobsala (2011) in the peri-urban area of Ngaoundere, had also shown that the number of live trees fell in savannas affected wood cut. Indeed, there are a lot of dead stems in savannas where the logging and bush fire practices are very recurrent. The mortality of species changed by site and species. Species that have the important number of dead stems are: Syzygium guineens var. macrocarpum (30 stems/ha), Hymenocardia acida (29 stem/ha), Piliostigma thonningii (27 stems/ha) and Annona senegalensis (Tchobsala, 2011). This mortality may be due to the repeated wood cut each year or grazing of young suckers and the trampling releases by animals in pasture sites. In wet savannas of Adamawa, the mortality rate of the stems is higher in the site logging without fire than the control and sites cought by bush fires. These differences reflect a regressive dynamic of vegetation. Faye et al. (2008) have also observed that the uncontrolled wood cutting is an important factor in the regressive dynamics of ligneous.

Tchobsala (2011) found that the mortality rate of seedlings and wood is very remarkable in the tree, shrubby savanna and gallery forests because of wood cutter and collector activities. Our work has shown that Shannon index is not very strongly low, despite the reduction of numbers of live trees in savannas due to wood cut and bush fires practices. These results are similar to those of Tchobsala et al. (2010) who found that Shannon index (ISH) varies between 2.56 to 3.27 and Pielou fairness (EQ) from 0.37 to 0.47 . Ndjouondo and Dibong (2014) have observed the same phenomenon at the floristic and ecological inventory of the aquatic macrophyte of Kambo River in Douala (Cameroon) where they showed that ISH varies from 1.45 to 3.16. Coulibaly et al. (2013) working on the diversity and configuration of the woody flora around the apiary in transition zone forest-savannas found that Pielou fairness (EQ) varies from 0.82 to 0.87 in transition zone between forest and savanna. These results are different from the current study. It could be a phenomenon of ecological resilience when the savannas were traumatized by the wood cut and bush fires. Species may be adapted through natural regeneration or by the phenomena of zoochory, anemochory, endozochory, epizoochory, etc. The present study results are similar to those of Masharabu et al. (2010) Tchobsala et al. (2010) who showed that the dispersal factors are responsible for the restoration of forests damaged by human activities. However our results differ from those of Adingra et al. (2014) who found $65.70 \%$ of the endozochory, $19.81 \%$ anemochory and $9.90 \%$ of epizoochory in the Forest of the Banmo (Ivory Coast). The reconstruction of a savannah cought by bush fires is mostly due to the phenomenon of anemochory. Anemochory is very high in the vegetation because of scattered trees in places and the massive presence of species with diaspores that are easily 
transported by wind (Tchobsala, 2011) found that Hymenocardia acida and Piliostigma thonningii have a strong power of regeneration in Ngaoundere savannas. Furthermore, distributions of rainfall and water availability in the soil are the main factors that regulate the rhythms of production and phenology of trees in the savanna (Devineau, 2010). Research has shown that regeneration rate of ligneous varies from $74.76 \%$ to 85.87\%. This result differs from that of Baggnian et al. (2013) who obtained a lower regeneration rate (39\%) on assisted natural regeneration of ligneous in Niger. In terms of phytogeographical distribution of recorded species, it is the pan-tropical species (PAN) (37.23\%) that are more important in the shrubby savannah than the tree savannah (23.85\%). The cosmopolitan species (COS), paleotropical (PAL), African multiregional (PRA), afrotropical (AFt) and Sudano Zambezian (SZ) represent respectively $7.45 \%, 8.51 \%, 2.13 \%, 14.89 \%$ and $29.79 \%$ in shrubby savannah and $5.38 \%, 10.77 \%$, $6.15 \%, 18.46 \%$ and $23.08 \%$ in the tree savannah.

The poorly represented species are not in the phytogeographical distribution. Our results are similar to those reported by Tchobsala (2011) who showed that the pan-tropical species (96.80\%) are dominant in Adamawa region. Bangirinama et al. (2011) showed that species are widely geographically distributed (39\%) from the analysis of the flora fallow in Burundi. These results are different from those from Melom et al. (2015) on the floristic and ecological characteristics of plant formations in Massenya Chad (Central Africa). Raunkiaer classification (1934) was adopted to assess the nature and degree of adaptation of plants during the unfavorable period (Table 5). These results are different from those of Tchobsala and Mbolo (2013) but similar to those reported by Biba (2013) who found that more than half of the families identified in the pastures of Wakwa are represented by only one species. However, these results differ from those of Baggnian et al. (2013) who listed 26 tree species, classified into 16 families. Poaceae and Asteraceae are mostly represented in both savannas.

\section{Conclusion and perspectives}

The number of rejection is classified in this order: site cutting without fire (CSF) site cutting with fire (CAF) control site (ST), the number of rejection changes to 1422 stern/ha; 1086 sterns/ha and 914 sterns/ha in the tree savanna and 554 sterns/ha, 282 stern/ha and 223 sterns/ha in the shrubby savanna respectively for CSF, $\mathrm{CAF}$ and control site. The regeneration rate is high for some species such as Hymenocardia acida (10.13\%;
$30.57 \%$ and 14.56\%); Syzygium guineense var. macrocarpum (26.44\%; 8.38\% and $17.09 \%)$, Harungana madagascariensis (14.21\%; $10.96 \%$ and $0.20 \%)$ respectively in CSF, CAF and ST in the tree savanna. But in the shrubby savanna Piliostigma thonningii (38.44\%; $18.79 \%$ and $35.87 \%)$; Annona senegalensis (15.16; $42.20 \%$ and $21.97 \%)$ then Croton macrostachyus $(12.82 \% ; 2.48 \%$ and $7.62 \%)$ that have respectively in $\mathrm{CSF}, \mathrm{CAF}$ and control site are the species that have the higher regeneration rate. The regeneration rate of species changes according to the vegetation and treatment. In the tree savanna control site has $90.22 \%$ of regeneration rate followed by CSF $(85.97 \%)$ then CAF with $81.41 \%$. The dispersal agents of seed are water, wind and animals. These agents are responsible for the recovery of a savanna disturbed by human activity. For a natural regeneration and sustainable management of natural resources it is advised to use controlled method of wood cut without fire by avoiding rejection each year in the same plot. It would be important to study the mechanism of species adaptation on wood cut and bush fire; evaluate carbon sequestration rate of important species and finally to develop a sustainable management will require the integration of populations in decision making for the control of uncontrolled wood cutting and bushfires.

\section{Conflict of interest statement}

Authors declare that they have no conflict of interest.

\section{Acknowledgement}

We thank the population of Bini and Dori for their willingness and assistance during our field work.

\section{References}

Adingra, O.M.M.A., Kassi, J.N., Yongo, D.O., 2014. Systematic analysis and phyto classified forest of Bamo (Ivory Coast). J. Anim. Plant Sci. 23(2), 3629-3633.

Amougou, J.A., Abossolo, S. A., Tchindjang, M., 2015. Variabilité des précipitations à Koundja et à Ngaoundéré en rapport avec les anomalies de la température de l'océan atlantique et el NINO. Rev. Ivoir. Sci. Technol. 25 (2015), $111 \mathrm{p}$.

Ancey, V., 1996. Economic trajectories of pastoral livestock: livestock farmers in northern of is very of Ivory Coast. In: High School Studies in Social Sciences, Paris. 137p.

Anonymous, 2015. The importance of biodiversity and transformation of the physical environment. 2p.

Baggnian, I., Adamou, M. M., Adam, T., et al., 2013. Impact of assisted natural regeneration of woody management methods (RNA) on ecosystem resilience in south-central 
Niger. J. Appl. Biosci. 71, 5745-5751.

Bangirinama, F., José Bigendako, M., Havyarimana, F., Bogaert, J., 2011. Analyse de la flore des jachères du Burundi. Bull. Sci. Inst. Natl. Environ. Conserv. Nat. 10, $1-19$.

Barbault, R., 1992. Population Ecology: Dynamic, Structure and Evolution. Masson, Paris. 273p.

Bellefontaine, R., Petit, S., Pain-Orcet, M., Deleporte, P., Bertault, J., 2001. Trees outside forest towards a better consideration. FAO document repository departments of forests, Paris. 16p.

Biba, H. P., 2013. State of degradation and management of pastoral resources in pasture forage station Wakwa (Adamaoua, Cameroon). Memory Master II. 33p.

Bonn, S., 2004. Dispersal of plants in the Central European landscapes dispersal processes and assessment of dispersal potential exemplified for endozoochory. Ph.D. thesis, Universität Regensburg. 118p.

Boutonnet, J.P., Griffon, M., Viallet, D., 2001. Competitiveness of livestock production in Sub-Saharan and Madagascar. MAE, Paris, France. 191p.

Braun-Blanquet, J., 1932. Plant Sociology. The Study of Plant Communities. McGraw Hill Publ., New-York and London. 439p.

Coulibaly, S., Ouattara, D., Edorh, T.T., Koudegnan, C.M.M., Kamanzi, K., 2013. Diversity and configuration of woody flora around the apiary in transition zone forest-savanna of the Ivory coast. Eur. Scient. J. 9(6), 227-239.

Daget, P., Poissonnet, J., 1972. A phytosociological analysis of grassland. Ann. Agron. (INRA, Paris) 22(1), 32- 41.

Dansereau, P., Lems, K., 1957. The grading of dispersal types in plant communities and their ecological significance. Contib. Inst. Bot. Univ. Montreal. 71, 1-52.

Degrande, A., Essomba, H., Bikoue, M.C., Kamga, A., 2007. Domestication, gender and vulnerability. Participation of women, youth and the poorest to the domestication of agroforestry trees in Cameroon. ICRAF Working Paper No. 48. Yaoundé, ICRAF-WCA/HT. 45p.

Devineau, J. L., 2010. To what extent does land-use affect relationships between the distribution of woody species and climatic change A case study along an aridity gradient in western Burkina Faso. Plant Ecol. 212, 959-963.

Dogmo, 2002. Floristic and ethno-botanical studies in a village in the forest zone of Cameroon. Master thesis, University of Yaoundé I, Cameroon. 72p.

FAO, 2002. Report on the World's Soil Resource. 96p.

Faye, E. H., 2002. Dynamic of woody regeneration during the growing phase in a semi-continuous culture system in southem Senegal. Conference, 27-31 May 2002, Garoua, Cameroon.

Faye, O., Ousmane Faye, Dupressoir, A., Weidmann, M., Ndiaye, M., Alpha Sall, A., 2008. One-step RT-PCR for detection of Zika virus. J. Clin. Virol. 43, 96-101.

Frontier, S., Pichod-Viale, D., 1993. Ecosystems: Structure, Operation, Evolution. Masson, Ecology Collection 21. Paris. 392p.

Gignoux, J., Menaut, J.C., Noble, I. R., Davies, I.D., 1997. A spatial model of savanna function and dynamics: model description and preliminary results. In: Dynamics of Tropical Communities (Eds.: Newbery, D. M., Prins, H.H.T., Brown, N.D.). Vol. 37 of Annual Symposium of the BES. pp.361-383.

Guedje, N. M., 2002. Population management of trees as tools for sustainable exploitation of non- timber forest products: the example of Garcinia elucida (South-Cameroon). Ph.D. Thesis, University of Brussels, Belgium. 221p.

Ibrahima, A., Schmidt, P., Ketner, P., Mohren, G.J.M., 2002. Plant biomass and nutrient cycling in there dense humid tropical forest of southern Cameroon. The TropenbosCameroon Programme, Kribi, Cameroon. 33p.

Jeltsch, F., Weber, G. E., Grimm, V., 2000. Ecological buffering mechanisms in savannas: A unifying theory of long-term tree-grass coexistence. Plant Ecol. 161(1), 161171.

Louppe, D., Ouattara, N., Coulibaly, A., 1995. Effects of bush fire on vegetation. Wood Trop. For. 245, 59-69.

Mapongmetsem P.M., Nkongmeneck B.A., Rongoumi, G., Nguemo Dongock, D., Dongmo, B., 2011. Impact of land use on the shelf Vitellaria paradoxa Gaertn.f. (Sapotaceae) in the region of the Sudan Guinean savannas. Int. J. Environ. Studies. 68(6), 851-872.

Masharabu, T., Noret, N., Lejoly, J., Bigendako, M. J., Bogaert, J., 2010. Comparative study of floristic parameters of national Ruvubu, Burundi. Geo-Eco-Trop. 34, 29-44.

Melom, S., Mbayngone, E., Bechir, A. B., Ratnan, N., Mapongmetsem, P. M., 2015. Floristic and ecological characteristics of plant communities of Massenya in Chad (Central Africa). J. Anim. Plant Sci. 25, 3799-3813.

Ndam, N., 1998. Tree regeneration, vegetation dynamics and the maintenance of biodiversity on Mount Cameroon: The relative impact of natural and human disturbance. Thesis, University of Wales, Bangor, UK. 278 p.

Ndjouondo, G.P., Dibong, S. D., 2014. Floristic inventory and ecology of aquatic macrophytes of the Kambo River to Douala (Cameroon). J. Appl. Biosci. 80, 7152-7154.

Ntoupka, M., 1994. Impact of the management of organic light on the mineral status of soil and corps in Soudan savanna pitched a born Ngaoundere, Cameroon. 6p.

Peltier, R., Forkong, C. N., Mama, F., Ntoupka, M., Manlay, R., Henry, M., Morillon, V., 2007. Carbon stock assessment and wooden reproduction of Shea park northeastern Cameroon. Wood Trop. For. 294(4), 16-50.

Pielou, E. C., 1966. Shannon's formula as a measure of species diversity: Its use and misuse. Am. Nat. 100, 463-465.

Raunkiaer, C., 1934. The forms of plants and statistical plant geography. Clarendron Press, Oxford. 632p.

Reynolds, J.F., Maestre, F. T., Kemp, P. R., Stafford-Smith, D. M., Lambin, E., 2007. Natural and Human Dimensions of Land Degradation in Drylands: Causes and Consequences. In: Terrestrial Ecosystems in a Changing World (Eds.: Canadell, J.G., Pataki, D.E., Pitelka, L.F.). Part of the series Global Change - The IGBP Series. pp.247-257.

Sere, C., 1994. Characterization and quantification of livestock 
production systems. In: FAO/OPHD. FAO, Rome. 13p.

Tchobsala, 2011. Impact of wood logging on the natural vegetation of the suburban area of Ngaoundere (Adamaoua). Ph.D. thesis, University of Yaoundé I, Cameroun. 204p.

Tchobsala, Amougou, A., Mbolo, M., 2010. Impact of wood cuts on the stucture and floristic diversity of vegetation in the peri-urban zone of Ngaoundere, Cameroon. J. Ecol. Natural Environ. 2(11), 235-258.

Tchobsala, Mbolo, M., 2013. Characterization and impact of wood logging on plant formation in Ngaoundéré District, Adamaoua Region, Cameroon. J. Ecol. Natural Environ. 5(10), 265-277.
Tchotsoua, M., Gonne, B., 2010. Socio-economic crises to environmental crises in the highlands Adamaoua region, Cameroon. http://hal.cirad.fr/cirad-00471335.

Vittoz, P., Engler, R., 2007. Seed dispersal distances: A typology based on dispersal modes and plant traits. Bot. Helv. 117, 109-124.

Walker, B. H., Noy, M. I., 1982. Aspects of the stability and resilience of savanna ecosystems. In: Ecology of Tropical Savannas (Eds.: Huntley, B.J., Walker, B.H.). Vol. 42 of the series Ecological Studies. pp.556-590.

Yonkeu, S., 1993. Pastures vegetation of Adamaoua (Cameroon). Ecology and potential pastoral. Ph.D. thesis (Biological Sciences). Univ. Rennes I. France. 207p.

\section{How to cite this article:}

Tchobsala, Dieudonne, R., Adamou, I., Marie, M., 2016. Impact of wood cutting and bush fire on the dynamic of regeneration in the Guinea savanna of Adamawa Region. Int. J. Curr. Res. Biosci. Plant Biol. 3(9), 114-131. doi: http://dx.doi.org/10.20546/ijcrbp.2016.309.015 